\title{
Review \\ Neurological Complications of COVID-19: Underlying Mechanisms and Management
}

\author{
Ghaydaa A. Shehata ${ }^{1}$, Kevin C. Lord $^{2}{ }^{2}$, Michaela C. Grudzinski ${ }^{3}$, Mohamed Elsayed ${ }^{4}$, Ramy Abdelnaby $^{5}$ D \\ and Hatem A. Elshabrawy ${ }^{6, *}$
}

1 Department of Neurology and Psychiatry, Assiut University Hospitals, Assiut 71511, Egypt; ghaidaa.abozaid@med.aun.edu.eg

2 Department of Physiology and Pharmacology, College of Osteopathic Medicine, Sam Houston State University, Conroe, TX 77304, USA; kcl043@shsu.edu

3 College of Osteopathic Medicine, Sam Houston State University, Conroe, TX 77304, USA; mcg043@shsu.edu

4 Department of Psychiatry and Psychotherapy III, University of Ulm, Leimgrubenweg 12-14, 89075 Ulm, Germany; mohamed.elsayed@uni-ulm.de

5 Department of Neurology, RWTH Aachen University, Pauwelsstraße 30, 52074 Aachen, Germany; rabdelnaby@ukaachen.de

6 Department of Molecular and Cellular Biology, College of Osteopathic Medicine, Sam Houston State University, Conroe, TX 77304, USA

* Correspondence: hatem.elshabrawy@shsu.edu; Tel.: +1-(936)-202-5216

Citation: Shehata, G.A.; Lord, K.C.; Grudzinski, M.C.; Elsayed, M.; Abdelnaby, R.; Elshabrawy, H.A. Neurological Complications of COVID-19: Underlying Mechanisms and Management. Int. J. Mol. Sci. 2021, 22, 4081. https://doi.org/ $10.3390 /$ ijms22084081

Academic Editor: Jordi Pérez-Tur

Received: 26 March 2021

Accepted: 13 April 2021

Published: 15 April 2021

Publisher's Note: MDPI stays neutral with regard to jurisdictional claims in published maps and institutional affiliations.

Copyright: (c) 2021 by the authors. Licensee MDPI, Basel, Switzerland. This article is an open access article distributed under the terms and conditions of the Creative Commons Attribution (CC BY) license (https:// creativecommons.org/licenses/by/ $4.0 /)$.
Abstract: COVID-19 is a severe respiratory disease caused by the newly identified human coronavirus (HCoV) Severe Acute Respiratory Syndrome Coronavirus-2 (SARS-CoV-2). The virus was discovered in December 2019, and in March 2020, the disease was declared a global pandemic by the World Health Organization (WHO) due to a high number of cases. Although SARS-CoV-2 primarily affects the respiratory system, several studies have reported neurological complications in COVID-19 patients. Headache, dizziness, loss of taste and smell, encephalitis, encephalopathy, and cerebrovascular diseases are the most common neurological complications that are associated with COVID-19. In addition, seizures, neuromuscular junctions' disorders, and Guillain-Barré syndrome were reported as complications of COVID-19, as well as neurodegenerative and demyelinating disorders. However, the management of these conditions remains a challenge. In this review, we discuss the prevalence, pathogenesis, and mechanisms of these neurological sequelae that are secondary to SARS-CoV2 infection. We aim to update neurologists and healthcare workers on the possible neurological complications associated with COVID-19 and the management of these disease conditions.

Keywords: SARS-CoV-2; COVID-19; encephalitis; encephalopathy; seizures; neurological; management; cerebrovascular; stroke; Guillain-Barré syndrome; headache; myalgia; dizziness

\section{Introduction}

In December 2019, the novel coronavirus, Severe Acute Respiratory Syndrome Coronavirus-2 (SARS-CoV-2), was identified as the causative agent of the acute atypical cluster of pneumonia cases in the city of Wuhan, China [1]. In February 2020, the World Health Organization (WHO) named the disease COVID-19 [2]. Although initially identified by respiratory symptoms, there have been increasing reports describing the copresentation of nonspecific neurological symptoms, including headache, dizziness, fatigue, and myalgia, impacting greater than $80 \%$ of all hospitalized patients [3]. What had previously been described only by pulmonary symptoms is now recognized by multiple neurological complications. Current data correlate the acuity of COVID-19 and mortality in critical care patients to the severity of neurological diseases, including acute necrotizing encephalopathy, encephalitis, epilepsy/seizures, and ataxia, increasing the risk of brain damage [4]. Additionally, peripheral nervous system (PNS) complications have been re- 
ported, including hypogeusia, hyposmia, Guillain-Barré syndrome, and skeletal muscle injury [5].

In this review, we aim to provide updates to the most current neurological complications resulting from COVID-19 and the treatment guidelines for these conditions.

\section{Search Strategy and Selection Criteria}

We performed a systematic search on PubMed utilizing the search terms "Coronavirus and Neurological," "SARS-COV-2 and Neurological," and "COVID-19 and management strategies (neurological or stroke or encephalitis or encephalopathy or seizures)" published between January 2019 and February 2021, yielding 5378 articles. We further filtered for articles in English, yielding 5212. After duplications and articles not relevant to the purpose of this review, we evaluated over 750 publications resulting in the 241 we used to support our review.

\section{Coronaviruses and Neurological Complications}

The blood-brain and blood-cerebrospinal fluid (CSF) barriers are structured to prevent the invasion of the brain by pathogens and toxic molecules [6]; however, this is not totally impermeable. There are multiple mechanisms by which neurotropic viruses are able to traverse the blood-brain barrier (BBB), but the most common route is the hematogenous route, which starts by entering the bloodstream causing viremia $[7,8]$. Once in the blood, viruses are able to cross the BBB via transcytosis or the infection of endothelial cells $[9,10]$, infected monocytes ("Trojan Horse" mechanism) [9], and paracellularly via disrupted tight junctions in the endothelial cells due to inflammation caused by the viremia $[7,9]$. Another route not dependent on viremia includes the coordination of dynein and kinesins proteins in the transport of the virus into the CNS using infected motor or sensory nerves [7]. Viruses can also enter the CNS through olfactory sensory neurons [7]. The latter is a more common route for respiratory coronaviruses [10].

To date, seven CoVs have been associated with diseases in humans, which include HCoV-OC43, HCoV-229E, HCoV-NL63, HCoV-HKU1, Middle East Respiratory Syndrome$\mathrm{CoV}$ (MERS-CoV), Severe Acute Respiratory Syndrome Coronavirus (SARS-CoV), and most recently SARS-CoV-2 [11-14]. Only SARS-CoV, MERS-CoV, and SARS-CoV-2 are recognized as causative agents of severe respiratory diseases, whereas all other human coronaviruses (HCoVs) typically present as mild diseases [15-17].

Not different from many other viruses [7,18], CoVs are known to cause neurological complications [19-23]. However, the neuroinvasive mechanisms have not been well understood. Murray et al. presented the first evidence of the association of $\mathrm{HCoVs}$ with neurological disease in multiple sclerosis (MS) patients [24,25], with later studies confirming HCoV-229E and HCoV-OC43 in patients diagnosed with Parkinson's disease, Schizophrenia, Alzheimer's disease, and meningoencephalitis [26]. A potential mechanism for CNS infection was suggested in a 2004 case study reporting the presence of $\mathrm{HCoV}-\mathrm{OC} 43$ in nasopharyngeal and CSF samples of a child who was diagnosed with acute disseminated encephalomyelitis [19]. These findings were supported by St-Jean et al., who described the route of $\mathrm{HCoV}-\mathrm{OC} 43$ infection of mice CNS through the olfactory bulb seven days after a nasal infection leading to acute encephalitis [20]. Additional murine studies confirmed the development of acute encephalitis in HCoV-OC43-infected BALB/c mice and HCoVOC43-induced apoptosis in mice and rat neuronal cells [27]. These findings highlight the neurotropic characteristics of $\mathrm{HCoVs}$ and their ability to infect the CNS.

Soon after the emergence of SARS-CoV in 2002-2003, neurological complications were reported in SARS-CoV patients [28]. In addition to regular symptoms, such as fever, chills, productive cough, and diarrhea, patients developed neurological complications such as seizures, convulsions, and loss of consciousness during the course of the disease [29]. Tests later confirmed the presence of SARS-CoV in the CSF. With the new awareness of the pervasiveness of the disease, the examination of samples from patients who have died of SARS-CoV has revealed the presence of the SARS-CoV-N protein and viral RNA in 
several organs, including the stomach, small intestine, kidney, sweat glands, liver, and cerebrum [30]. The neurotropic property of SARS-CoV was further confirmed by a study in C57BL/ 6 mice, which showed that intranasal infection of mice eventually led to the infection of mice brain [31]. The previous findings indicate that SARS-CoV is capable of causing systemic infections, including CNS infections. In 2016, a study showed that some children who suffered acute encephalitis had a concurrent $\mathrm{HCoV}$ infection [32].

Similar to other HCoVs, SARS-CoV-2 has been associated with neurological complications, which are now recognized as initial symptoms in conjunction with the typical respiratory manifestations [33]. The most common neurological manifestations include headache, lethargy, unstable gait, ataxia, and seizures, in addition to PNS manifestations such as loss of taste and smell, vision impairment, nerve pain, and malaise [34]. The most serious developing neurological diseases include polyneuritis, Guillain-Barré syndrome (GBS), meningitis, encephalitis, and encephalopathy, in addition to cerebral hemorrhage and infarction [34]. Liotta et al., in a study of 509 COVID-19 patients, showed that $82 \%$ of these patients experienced neurological complications, which manifest early in $42 \%$ of patients and in $63 \%$ of patients at hospitalization [3]. Adjusting for age and severity of disease, younger patients and those presenting with severe COVID-19 are more likely to present with neurological manifestations, while older patients are more likely to develop a neurological disease (encephalopathies). These findings have been further supported by another study of 214 patients. In this study, 78 patients (36.4\%) suffered from neurological consequences to COVID-19 [35]. These neurological complications manifest as CNS-related complications, such as dizziness, headache, impaired consciousness, acute cerebrovascular disease, ataxia, and seizure, or as PNS manifestations, such as loss of taste and smell, vision impairment, and nerve pain, as well as skeletal muscular injury. There was a higher incidence of neurological complications in patients with severe COVID-19 than in mild COVID-19 patients.

All the previous manifestations depend on the SARS-CoV-2 infection of host target cells; primarily unciliated bronchial epithelial cells and type II pneumocytes in the lung, after binding to cell surface receptors; angiotensin-converting enzyme 2 (ACE2), basigin (BSG; CD147), and neuropilin-1 (NRP-1) [36-38]. Cellular proteases such as TMPRSS2, furin, and cathepsins are required for priming the viral spike (S) protein, a process that is essential for viral entry after binding to host cell receptors [36]. Human brain single-nuclear RNA sequencing (RNA-seq) data suggest low or no expression of ACE2 on different human brain cells and its microvasculature [39]. However, higher expression of other SARS-CoV-2 receptors, such as BSG and NRP-1, was reported in many brain cell types [39]. Moreover, host cell proteases are also expressed at different levels in most brain cells [39]. The previous findings suggest that the brain may be susceptible to SARS-CoV-2 invasion and infection.

\section{Mechanisms of SARS-CoV-2 Invasion of the CNS}

Studies have reported the presence of SARS-CoV-2 in the CSF and postmortem brain tissue of COVID-19 patients with encephalitis [40-48]. However, there are contradictory findings that may indicate that the neurological complications are due to severe systemic inflammation and not the direct invasion of the brain [49-56].

It has been suggested that SARS-CoV-2 could invade the CNS via the same routes as other HCoVs [hematogenous route (Figure 1A) or by using retrograde or antegrade transport mechanisms from peripheral nerves to the CNS (Figure 1B)] [33,40,57-61].

One possible mechanism of the hematogenous route is binding to SARS-CoV-2 receptors on BBB endothelial cells, passing through endothelial cells by transcytosis, and finally reaching the brain (Figure 1A) [40,62]. The infection of endothelial cells does not involve any viral replication [33]. Because BSG and NRP1 are more highly expressed than ACE2 in the brain microvasculature, it is more likely that the SARS-CoV-2 would utilize these receptors to enter the CNS [39]. The other proposed mechanism involves infecting immune cells that express ACE2, such as monocytes, granulocytes, and lymphocytes, ("Trojan horse" mechanism) (Figure 1A) [63-67]. The infected immune cells may then carry SARS-CoV-2 
to the CNS, where it can infect the brain [68]. SARS-CoV-2 viral RNA was detected in the lung macrophages of COVID-19 patients; however, viral replication in immune cells and immune infiltration of the brain need to be confirmed [69]. One additional mechanism is passing through disrupted endothelial cells' tight junctions (paracellular route) (Figure 1A).

A

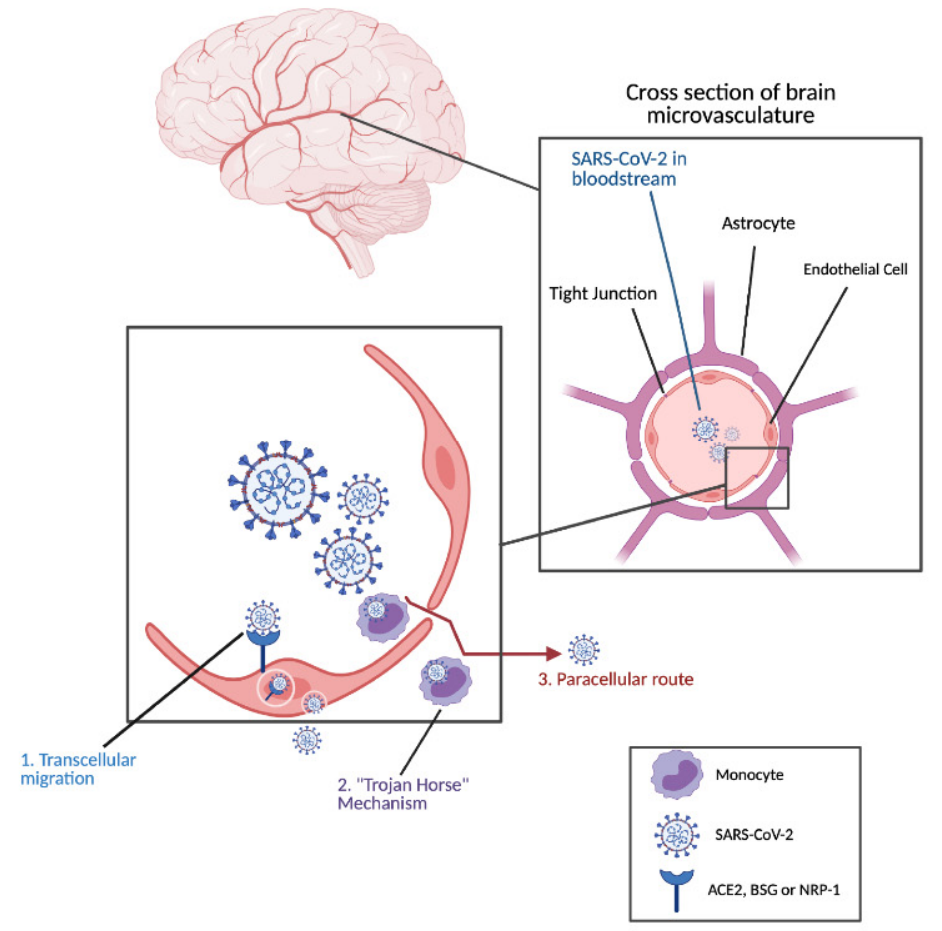

B

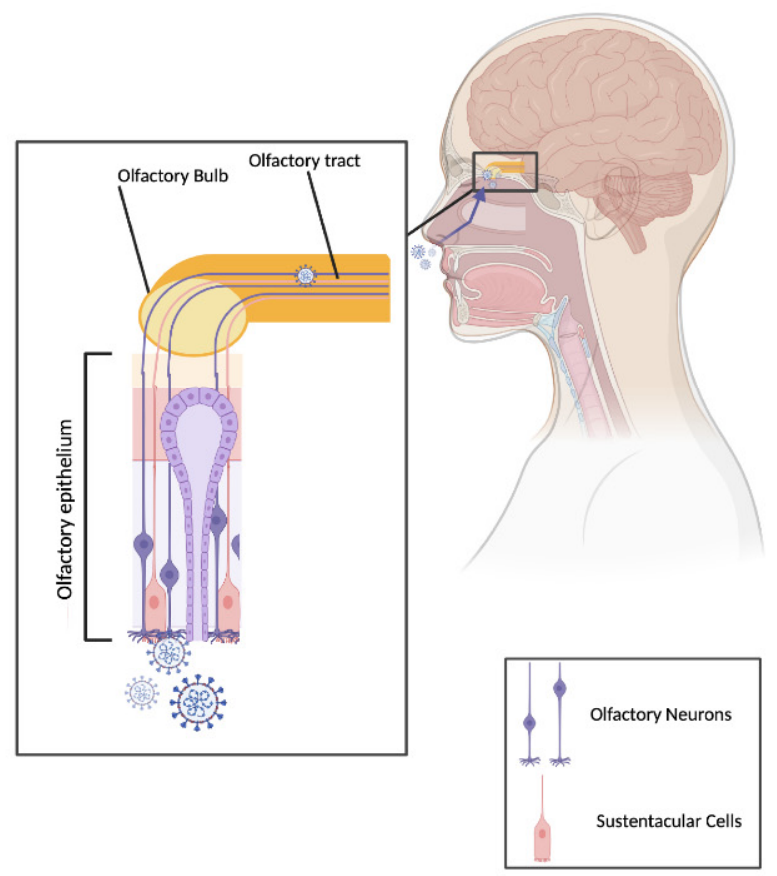

Figure 1. Mechanisms of SARS-CoV-2 invasion of the CNS. (A) Hematogenous route: Severe Acute Respiratory Syndrome Coronavirus-2 (SARS-CoV-2) invasion of CNS from the bloodstream is mediated by three mechanisms; 1 . Transcellular migration which involves binding of the virus to its receptors; ACE2, basigin (BSG), or neuropilin-1 (NRP-1), on brain microvasculature endothelial cells then crossing endothelial cells via transcytosis, 2 . Infecting immune cells which then carry the virus across the blood-brain barrier (BBB) endothelial cells into the CNS (Trojan Horse mechanism), and 3. Paracellular route by disrupting endothelial cells' tight junctions. (B) SARS-CoV-2 infects olfactory epithelium and reaches the CNS via the olfactory neurons. This figure was created with BioRender.com.

As mentioned earlier, SARS-CoV-2 may also reach the CNS via peripheral nerves, more specifically the olfactory sensory neurons (Figure 1B) $[57,58]$. The high expression of ACE2 and the priming protease, transmembrane serine protease 2 (TMPRSS2), in sustentacular cells, stem cells of the olfactory epithelium, and olfactory bulb may allow for retrograde or antegrade transport into the CNS [61,70-74].

\section{Neurological Disorders and Their Management in COVID-19 Patients \\ 5.1. Cerebrovascular Diseases}

Cerebrovascular complications have been documented in 5\% of COVID-19 patients, with $60 \%$ of these events attributed to an acute ischemic stroke $[35,75,76]$. The increased risk of these events is believed to be due to a hyperinflammatory/hypercoagulable state, and altered endothelial cell function resulting from the SARS-CoV-2 infection (Figure 2) [77-81]. Several studies have reported a significant increase in neutrophil-to-lymphocyte ratio (NLR), C-reactive protein (CRP), and serum ferritin in COVID-19 patients with ischemic stroke, which could predict mortality in these patients [82-87]. Neutrophilia (increase in neutrophils) described in these patients results in the overproduction of neutrophil extracellular traps (NETs), which has been shown to increase thrombi formation [88-90]. Furthermore, hypercoagulability and the increase in thrombi formation in COVID-19 pa- 
tients could be explained by impaired fibrinolysis, low levels of natural anticoagulants, and high levels of coagulation factors and antiphospholipid antibodies [91-94]. The formation of thrombi is further potentiated by SARS-CoV-2-mediated damage of the endothelium, which results in nitric oxide synthase (NOS) depletion and subsequent deficiency of NO [95]. NO deficiency increases the risk of stroke because NO is a potent vasodilator and an inhibitor of platelets and leukocytes adhesion to the endothelium [95].

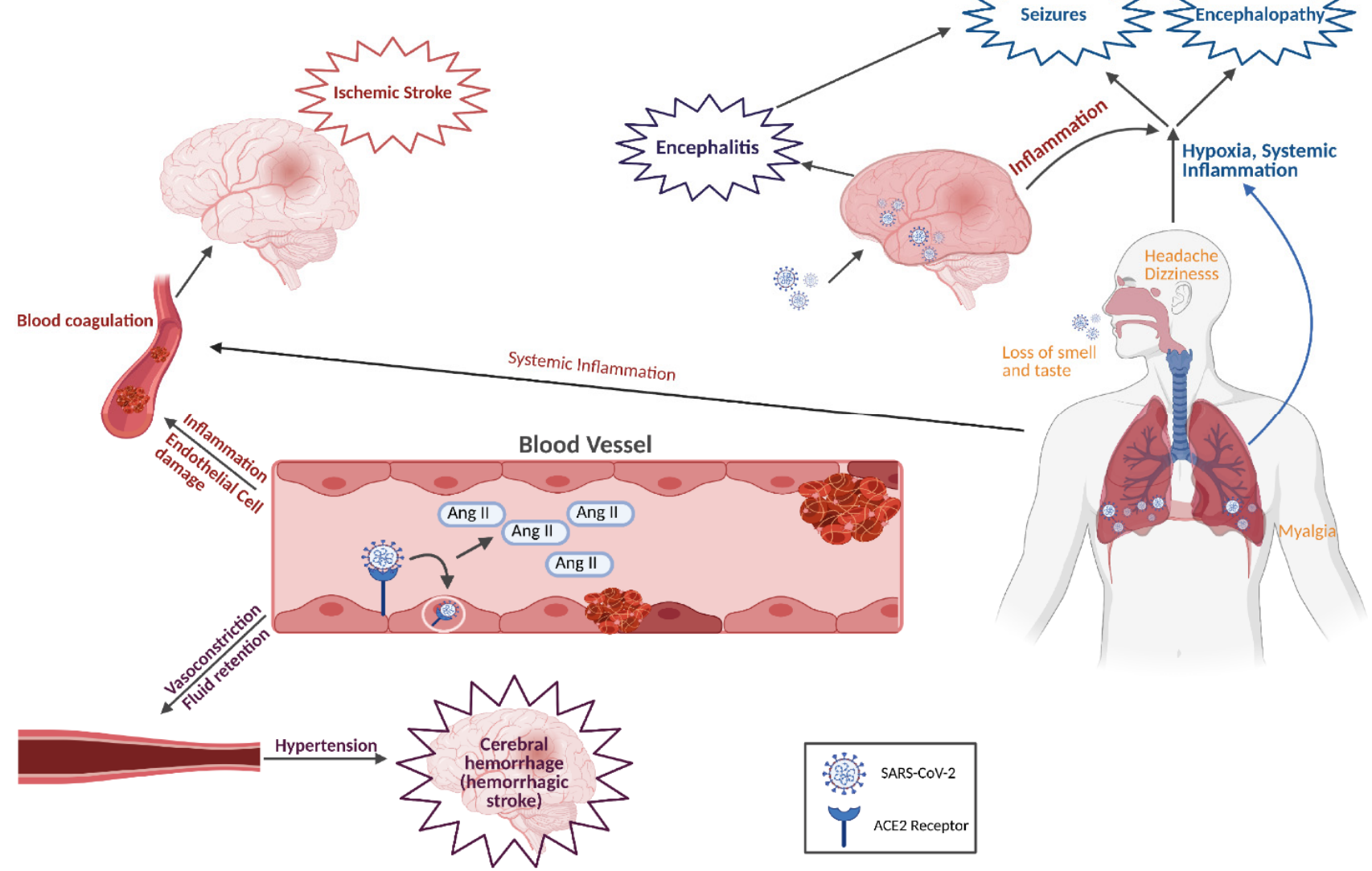

Figure 2. Mechanisms of COVID-19 neurological complications. Lung infection by SARS-CoV-2 results in severe inflammation, acute respiratory distress syndrome (ARDS), and hypoxia. This leads to hypoxia- and inflammation-induced encephalopathy and seizures. Brain damage due to viral replication may lead to encephalitis. Severe systemic inflammation could result in hypercoagulability which may eventually lead to stroke. Nonspecific symptoms due to nervous system affections include headache, dizziness, loss of taste and smell, and myalgia. Usage of ACE2 receptor; by SARS-CoV-2, to infect target cells, including endothelial cells, would deplete the receptor resulting in the accumulation of angiotensin II (AngII). High levels of AngII promote vasoconstriction, fluid retention, inflammation, and blood coagulation, which could result in ischemic or hemorrhagic stroke. This figure was created with BioRender.com.

Moreover, the internalization of ACE2, following the binding of SARS-CoV-2, leads to ACE2 depletion on the surface of endothelial cells, which may increase the incidence of ischemic stroke [96]. Data have shown a significant reduction in ACE2 expression on endothelial cells of SARS-CoV-2 patients [97]. Lack of ACE2 leaves angiotensin II (Ang II), a powerful vasoconstrictor, unregulated, thus increasing the risk of hypertension, blood coagulation, and ischemic stroke (Figure 2).

A case study has reported acute stroke-like symptoms and intracranial hypertension in a 75-year-old Australian man due to severe inflammatory response to COVID-19 [98]. The neurological involvement in this case was not discovered until Day 26 postinfection, which highlights the importance of clinical values, such as NLR, lymphocyte-to-CRP ratio (LCRPR), and lymphocyte-to-platelet ratio (LPR), as prognostic indicators of severe inflammation and possible neurological complications. Other studies have shown that 
COVID-19-induced severe inflammation and inflammatory infiltrates consisting of T cells, macrophages, and neutrophils contribute to the rupture of atheromatous plaques in patients with pre-existing atheromatous disease due to the production of proteolytic enzymes and endothelial cell disruption [99-101]. Although the use of protease inhibitors in these patients may be beneficial, they should be carefully used as they may promote SARS-CoV2-induced hypercoagulation.

Following the occurrence of ischemic stroke, the production of proinflammatory mediators from activated immune cells and ischemic brain tissue could further promote brain injury [102,103]. Therefore, the suppression of inflammation in ischemic stroke could help ameliorate brain damage following ischemic stroke. However, further studies are needed to prove the therapeutic utility of this approach.

In addition to ischemic stroke, intracranial hemorrhage was observed in $0.5 \%$ of COVID-19 patients, similar to what was seen in MERS-CoV patients [35,104,105]. Coagulopathies and vascular disorders have been associated with hemorrhage in COVID-19 patients (Figure 2) [106]. It is also possible that reduced levels of ACE2 on endothelial cells of the brain microvasculature lead to blood coagulation and increased blood pressure, which may result in the rupture of blood vessels and hemorrhage (Figure 2) [97].

The increased risk of hypercoagulable states has resulted in the suggested addendums for COVID-19 patients at risk of cerebral vascular incidents. [107-110]. The documented endothelial injury, changes in circulating prothrombotic factors, and increased stasis resulting from immobilization due to COVID-19 infection have warranted hypervigilance in the monitoring and prophylactic treatment of these patients. The International Society on Thrombosis and Hemostasis, American Society of Chest Physicians, and American College of Cardiology have approved interim guidelines for prophylactic treatment and management. However, it is important to note these are interim guidelines until quality evidence, supporting interventions different from current standard practice, are identified [111-113].

Current recommendations for monitoring hospitalized at-risk patients include baseline complete blood count, levels of fibrinogen, D-dimer, prothrombin time, activated partial thromboplastin time, and inflammatory markers such as CRP and IL-6. The frequency of these tests is determined by the severity of the patient's clinical presentations [114]. It is recommended that any abnormal findings in these measures are used for their prognostic value, and any changes to therapy should be the result of changes in signs or symptoms associated with stroke. Current treatment and management of patients presenting with active ischemic or hemorrhagic stroke do not differ from current recommendations, based on patients' pre-existing conditions.

The implementation of prophylactic anticoagulant treatment varies depending on pre-existing conditions. The use of anticoagulants presents with its own adverse effects. The outpatient recommendations are not different from current guidelines (https:/ / www. isth.org/page/Published_Guidance, accessed on 14 April 2021). However, as inpatient recommendations for the treatment and management of ischemic or hemorrhagic stroke due to COVID-19 are being evaluated, there is a consensus that thromboprophylaxis should be considered for all COVID-19 patients in intensive care units (ICUs) due to the increased risk of stasis $[79,115]$.

\subsection{Encephalitis, Acute Disseminated Encephalomyelitis, Encephalopathy, and Acute Necrotizing Encephalopathy}

Encephalitis and meningitis are characterized by inflammation of the brain parenchyma and meninges, respectively [116]. The patient presents with headache, fever, vomiting, convulsions, and impaired sensations [60]. SARS-CoV-2 was detected in brain tissues and the CSF of COVID-19 patients who presented with meningitis or encephalitis, which indicates that the virus itself may cause this complication by infecting and damaging the brain (Figure 2) $[40-42,60,117,118]$. However, COVID-19 patients could also present with acute meningoencephalitis with no detectable SARS-CoV-2 or any other virus in the CSF $[55,56,119]$. The previous findings indicate that other mechanisms such as severe inflammation could be involved in the development of meningoencephalitis in COVID-19 
patients. Based on the fatal consequences of encephalitis and meningoencephalitis, it should be considered as a possible complication in the management of COVID-19 patients. The early detection and treatment of meningoencephalitis are critical to prevent hemorrhagic encephalopathy that could be fatal.

Acute disseminated encephalomyelitis (ADEM) is another complication characterized by demyelination of CNS following viral infections particularly in children; however, occurrence in adults is reported [120]. MRI images of a 51-year-old woman, who has been diagnosed with COVID-19, showed several demyelinating lesions that are consistent with ADEM [121]. Post-COVID-19-ADEM was further confirmed by the CNS axonal damage and the lesions, in an autopsy of a 71-year-old COVID-19 patient, which are typical of ADEM [122].

Encephalopathy has also been described in 50\% of hospitalized COVID-19 patients $[123,124]$. A study of several patients who died of COVID-19 showed that a significant number experienced hypoxic encephalopathy (Figure 2) [123]. Encephalopathy is more common in COVID-19 patients with coexisting or previous systemic and/or neurological complications $[35,125]$. Several cases that presented with altered mental state and confusion subsequent to COVID-19 did not have any evidence of CNS infection, which is typical of most cases of encephalopathy $[125,126]$.

Acute necrotizing encephalopathy (ANE) often presents as neurological symptoms following viral infection, toxemia, and hypoxia [60]. Because SARS-CoV-2 infection results in viremia and hypoxia, it is not surprising that SARS-CoV-2 is a causative agent of encephalopathy (Figure 2) [60,97]. ANE was reported in cases with COVID-19, and preexisting conditions could increase the risk of ANE [125]. A brain MRI of patients showed bilateral hemorrhagic rim-enhancing lesions in the thalamic temporal lobes and subinsular regions [127-129]. The cytokine storm that is associated with SARS-CoV-2 infection is believed to damage the BBB and cause brain necrosis in patients with severe COVID-19 (Figure 2) [127-129].

Evaluation of the current literature does not indicate any changes or interim recommendations for COVID-19 patients that differ from the current recommended guidelines for the treatment and management of encephalopathy. However, because encephalopathy has been identified as a frequent finding among older COVID-19 patients [130] and is associated with poorer outcomes among this cohort [3,131], there has been hypervigilance in testing for COVID-19 among these patients. Following the diagnosis of encephalitis, meningoencephalitis, or ANE, recommendations are to start with CSF PCR analysis for the presence of SARS-CoV-2 or other potential contributing viral infections such as Herpes Simplex Virus (HSV) [132]. Furthermore, the combined use of MRI and EEG appears to be very important in the detection of these cases [132].

\subsection{Seizures}

It is expected that some COVID-19 patients will develop seizures as a consequence of hypoxia, metabolic derangements, severe inflammation, organ failure, and cerebral affection (Figure 2) [41,133]. Indeed, seizures in COVID-19 patients have been reported due to SARS-CoV-2-induced brain damage, high levels of inflammatory mediators, and viral-induced encephalitis or meningitis [41,134-136]. Infection with SARS-CoV-2 reduces the seizures threshold which can worsen the case in epileptic patients or it can lead to seizures in patients with no history of seizures [137-140]. It is of note that seizures could be one of the initial symptoms in COVID-19 patients [141]. Focal seizures have been described in COVID-19 patients in addition to generalized tonic-clonic seizures [134]. Other than its presentation in adult COVID-19 patients, there were cases of seizures in COVID-19 children who present with fever or no fever (afebrile seizures) [142,143]. Therefore, it is important to consider seizures in the diagnosis of COVID-19 in children regardless of the presence or absence of fever $[142,143]$. The management of seizures could include the use of antiepileptic drugs and monitoring of seizures by electroencephalography especially in severe COVID-19 patients [135]. It is critical to diagnose and recognize the typical and 
atypical presentation of seizures in COVID-19 patients to better diagnose, treat, and avoid any long-term complications of seizures [144].

Current recommendations for the treatment and management of seizures and epilepsy for patients infected with COVID-19 do not differ from current guidelines. However, awareness of drug-drug interactions with COVID-19 treatment and the treatment for new or existing seizures must be considered when treating this patient population. The following discussion excludes the pediatric population because of limited early data that are reported among this group.

Many of the medications currently used in the treatment and management of COVID19 induce, or inhibit, and are metabolized by the hepatic cytochrome P450 enzymes (CYP450). These enzymes are also altered or involved in the metabolism of many of the antiepileptic drugs (AEDs) frequently used in the treatment of seizure disorders.

Lopinavir/ritonavir are protease inhibitors used in the treatment of COVID-19 [145]. These drugs are frequently used in combination and have been shown to induce multiple CYP450 enzymes (CYP2C9, 2C19, 1A2, and 2B6) and glucuronyl transferase [146]. This activity decreases the plasma concentration of lamotrigine (via glucuronyl transferase) and possibly phenytoin and valproate (via CYP enzymes), which are frequently used AEDs [147,148]. Additionally, lopinavir/ritonavir plasma concentration may be reduced when used concomitantly with carbamazepine, phenytoin, and topiramate due to the ability of these AEDs to induce the CYP3A4 enzyme which metabolizes lopinavir/ritonavir [148].

Remdesivir is an adenosine analog that targets the RNA-dependent RNA polymerase and blocks viral RNA synthesis [145]. To date, there is limited information regarding the metabolism of remdesivir; however, it is partially metabolized via CYP3A4 (10\%) [149]. This activity would result in reduced efficacy if used in combination with AEDs that induce this enzyme. Although there have been no drug interaction trials of remdesivir and concomitant AEDs it is important to note caution when used in combination with AEDs [150].

Currently, there is neither experimental nor clinical evidence for any noticeable drug interactions between AEDs and antivirals such as favipiravir, nitazoxanide, and interferonbeta which suggests that these antivirals do not require additional dosing considerations when used with AEDs in the management of COVID-19 patients presenting with seizures.

\subsection{Altered Mental State (AMS)}

Patients could present with confusion and delirium as early signs of COVID-19 without any of the respiratory symptoms [151]. Accordingly, the early detection of AMS may help in the proper treatment and prevention of COVID-19 spread. It has been estimated that $9 \%$ of COVID-19 patients have AMS [152]. We believe that AMS could be the result of direct invasion of the brain or damage resulting from high levels of inflammatory mediators due to the immune response to SARS-CoV-2 infection. We also believe that individuals with Alzheimer's disease (AD) and related dementias are at high risk of COVID-19 and its associated morbidity and mortality. That could be attributed to the difficulty in applying disease prevention measures such as washing hands, social distancing, and isolation at home.

Helms et al. reported that $118(84.3 \%)$ of 140 COVID-19 patients, who were treated in two intensive care units (ICUs) in France, had mental changes including delirium, agitation, and corticospinal tract signs [153]. MRI showed bilateral frontotemporal hypoperfusion. About $33 \%$ of the 45 survivors experienced a dysexecutive syndrome suggestive of the involvement of the frontal lobe, which is responsible for an individual's mental state [153]. Based on the above findings, we believe that changes in mental status could be an important diagnostic for COVID-19 because COVID-19 patients may only present with delirium and confusion.

Patients with pre-existing or developing mental illness due to COVID-19 are expected to be treated with psychotropic drugs along with the standard treatment for the viral illness. Benzodiazepines (oxazepam and lorazepam), antidepressants (citalopram and escitalo- 
pram), antipsychotics (olanzapine), and the mood stabilizer (valproate) are suggested as safe considering the tolerability and minimal drug-drug interactions [154-156].

\subsection{Guillain-Barré Syndrome (GBS)}

GBS can occur following infections such as Campylobacter jejuni, Epstein-Barr virus, and cytomegalovirus due to molecular mimicry between peripheral nerve antigens and antigens of these pathogens [157]. Antipathogen antibodies can then cross-react with peripheral nerve antigens, causing inflammation and neuronal damage [157]. GBS has been described in several cases of COVID-19 patients, which manifest as weakness in the lower limbs and paresthesia and may progress to tetraparesis $[49,158]$. Nerve roots are typically involved, which is characterized by increased protein concentration in CSF and normal white blood cell count (cytoalbuminologic dissociation) $[159,160]$. It is of note that demyelinating polyradiculoneuropathy and/or axonal damage are characteristics of GBS in COVID-19 patients [161,162]. GBS may manifest in individuals with COVID-19 even before the appearance of the typical flu-like symptoms [163]. Gupta et al. described the difference between GBS due to COVID-19 and other types of GBS [164]. COVID19 GBS is more prevalent in the elderly and males, and COVID-19 GBS patients may experience fever, cough, dyspnea, ageusia, hyposmia 5-14 days before the paresthesia, lower limb weakness, and facial weakness [164]. Unfortunately, COVID-19 GBS has residual weakness, dysphagia, and extended ICU stay than other GBS types. Variants of GBS such as Miller Fisher syndrome and polyneuritis cranialis have also been reported in COVID-19 patients $[4,163,165]$.

Management of GBS is best achieved by intravenous immunoglobulin (IVIG) treatment $[166,167]$. Lopinavir/ritonavir use in COVID-19 with peripheral neuropathies is controversial because one study showed that protease inhibitors may increase the risk of peripheral neuropathy in patients with HIV [168]. However, other studies have found that lopinavir/ritonavir does not increase the risk of distal sensory polyneuropathy in HIV patients [169].

\subsection{Skeletal Muscle and Neuromuscular Junction Complications}

Severe inflammation in critically ill COVID-19 patients could lead to neuromuscular junction dysfunction and myopathy $[170,171]$. The invasion of muscle cells, which express the ACE2 receptor, is also a possible mechanism $[170,171]$. On the other hand, the risk of COVID-19 infection increased with the use of immunosuppressive/immunomodulatory therapies in patients with autoimmune neuromuscular disorders [172-174].

We studied different reports to propose a protocol for the management of myasthenia gravis (MG) and Lambert-Eaton myasthenic syndrome (LEMS) during COVID-19 [175,176] and concluded the following.

The MG expert panel suggests that decisions to manage every patient should be individualized, patients should take more precautions with extraordinary measures, and MG patients on immunosuppressive therapy should continue taking the medications. Hydroxychloroquine should be avoided in COVID-19 patients with MS or LEMS as the drug is reported to worsen MG $[177,178]$. The delay in initiation of the B-cell depleting therapy (rituximab) increases the risk of worsening myasthenia or myasthenia crisis $[179,180]$.

\subsection{Neurodegenerative and Demyelinating Disorders}

It remains unclear whether SARS-CoV-2 infection is associated with the development of neurodegenerative diseases, such as multiple sclerosis (MS), Alzheimer's disease (AD), and Parkinson's disease (PD) [181]. There is also no evidence of the acceleration of these diseases in COVID-19 patients [181]. However, the high expression of ACE2 in CNS and the brain damage that SARS-CoV-2 causes could lead to long-term neurodegenerative diseases/complications [182]. MS is characterized by nerve demyelination and brain neurodegeneration due to immune-mediated inflammation [181]. The SARS-CoV2-mediated neurological damage that results from inflammation or direct invasion of the 
brain is similar to that caused by MS $[183,184]$. However, there is not enough evidence that SARS-CoV-2 leads to MS or that MS patients are more susceptible to COVID-19, its CNS involvement, or the reactivation of MS lesions due to SARS-CoV-2-mediated immune dysregulation [185-187]. A case of a 67-year-old woman who had MS and died of COVID-19 showed that SARS-CoV-2 did not infect neuronal or glial cells and infection did not result in disease exacerbation or reactivation of MS lesions [187]. The findings of the previous case are consistent with other studies, which showed that COVID-19 did not affect the course of autoimmune diseases [185,186].

$\mathrm{AD}$ is another neurodegenerative disease that is characterized by neuroinflammation and neuronal loss and has many risk factors, which include age [188]. Several studies have shown that $\mathrm{AD}$ development could correlate with infections including viral infections [188]. Because SARS-CoV-2 infects/damages the CNS and induces severe inflammatory responses, it is possible that the long-term effect on cognitive function could develop in COVID-19 survivors [189]. To date, there is not enough evidence that SARS-CoV-2 causes or increases the risk of developing $\mathrm{AD}$, as long-term studies are needed to draw this correlation. However, the infection of glutamate-producing and GABA-producing neurons by SARS-CoV-2 infection is a possible mechanism by which AD could develop secondary to COVID-19 [182].

Similar to AD, PD patients suffer from cognitive and memory issues in addition to the impairment of motor function [190]. Although ACE2 is widely expressed in CNS and SARS-CoV-2 infects and damages several sites in the brain, there is no direct evidence that SARS-CoV-2 induces or increases the risk of PD development or that PD patients are at higher risk of contracting SARS-CoV-2 [191,192]. There is not any evidence too that PD worsens during the course of COVID-19 disease [192]. However, it is highly possible that SARS-CoV-2 could be linked to PD development or its acceleration once more studies are conducted and follow-up of COVID-19 survivors is done over the next few years.

\subsection{Miscellaneous Complications}

The most common neurological symptoms associated with COVID-19 are headache, dizziness, myalgia, fatigue, hyposmia, hypogeusia, and visual impairment. These symptoms are seen in 30 to $45.5 \%$ of patients [35,193,194].

Headache is one of the most common neurological symptoms in COVID-19 patients and could be the first symptom of COVID-19 in a few patients (Figure 2) [35,195-197]. It occurred in 6-25\% of COVID-19 patients depending on the study, and the intensity is often described as moderate to severe [152,198-204]. It has been noticed that headache as a result of COVID-19 starts as moderate pain due to systemic spread of the virus, whereas after a few days, severe inflammation could lead to photophobia and neck stiffness [205].

Past medical histories of several COVID-19 patients indicate that headache has been a regular complaint [199]. However, there are other cases in which COVID-19 patients never had any headache in their medical history and only experienced headache after SARS-CoV-2 infection, which suggests that headache is a complication of COVID-19 [206]. It has been suggested that headache occurs in COVID-19 patients as a result of SARS-CoV-2 infection of the nasal cavity trigeminal nerve endings [198]. Furthermore, headache could be due to infection of endothelial cells of the vessels in the trigeminovascular system [198]. The high level of proinflammatory cytokines could also irritate the trigeminal nerve endings leading to headache [198]. In our opinion, in addition to all the above-described mechanisms, headache could also occur due to lack of sleep, isolation, and anxiety in COVID-19 patients. Despite being a common symptom in COVID-19, headache can be easily treated by analgesics.

Dizziness is also reported as one of the common neurological symptoms that presents in $8-9 \%$ of COVID-19 patients (Figure 2) $[35,207,208]$. It is even reported, in some COVID19 cases, to be more commonly occurring than headache [35]. A COVID-19 case for a 53-year-old woman was described, and dizziness was reported as an initial symptom along with dry throat, while fever, cough, and headache were absent [209]. Antiviral and 
other drug treatments resulted in case improvement. Therefore, it is important to watch for dizziness as one of the neurological complications that may help in the diagnosis of COVID-19 even in absence of respiratory symptoms.

Myalgia and fatigue have been commonly reported in COVID-19 patients (Figure 2) [35, $193,194,207,208]$. Depending on the study, fatigue was a complaint in $26-51 \%$ of patients, whereas $3-64 \%$ of patients had myalgia [210]. It has been postulated that myalgia in COVID-19 patients is due to severe inflammation and high levels of proinflammatory cytokines [211]. However, muscle invasion by SARS-CoV-2 remains a possibility because muscles express the ACE2 receptor. Some patients showed fatigue, muscle soreness, and elevated muscle enzyme levels such as creatine kinase all of which may be related to systemic inflammation and muscle damage [212].

Hyposmia (anosmia) and hypogeusia (ageusia) are loss of smell and taste, respectively, and they are among the most common early symptoms of COVID-19 (Figure 2) [213-215]. They are reported by up to $88 \%$ of COVID- 19 patients with mild or moderate disease and therefore could be used for the diagnosis of COVID-19 [35,216-219]. Anosmia could appear as an initial symptom and is not accompanied by nasal inflammation $[220,221]$. Using MRI, an abnormal appearance of the olfactory bulb has been described in COVID-19 patients [220,221]. Infection of the olfactory epithelium and trigeminal nerves by SARSCoV-2 may explain the loss of smell and taste in COVID-19 patients [222,223]. Because anosmia is highly prevalent and an early symptom of COVID-19, it can be used for the early diagnosis of COVID-19 [224]. This may help in the early isolation and treatment of COVID-19 patients, which could eventually result in a decline in the number of new cases.

Post-COVID-19 Neurological Syndrome (PCNS) indicates prolonged post-COVID-19 neurological symptoms. Several reports have shown that PCNS could present in the form of long-term symptoms that persist for months such as muscle pain and weakness, myopathy, sleep impairment, anxiety, depression, severe post-traumatic stress disorder (PTSD), dizziness, headaches, and anosmia $[225,226]$. The previous findings suggest that COVID-19 patients should be followed up after recovery for possible long-term postCOVID-19 neurological complications.

\section{Mechanisms of SARS-CoV-2-Induced Neurological Complications}

The high expression of ACE2 in the brain and peripheral nerves allows SARS-CoV2 to infect the nervous system and cause neurological damage, which is manifested as complications secondary to SARS-CoV-2 infection [57]. Because ACE2 has several physiological functions, including the regulation of blood pressure, its usage by SARS-CoV-2 as an entry receptor may lead to its depletion and the accumulation of Ang II [227-229]. Elevated Ang II would result in increased blood pressure due to vasoconstriction and fluid retention [229]. Moreover, high levels of Ang II would promote inflammation and blood coagulation. Complications due to ACE2 depletion could be manifested as cerebrovascular diseases in COVID-19 patients (Figure 2).

Acute respiratory distress syndrome (ARDS), which occurs as a consequence of severe SARS-CoV-2 infection, could lead to hypoxia that can have deleterious effects on the brain, including edema, congestion, and neuronal degeneration (Figure 2) [64,202,230]. This hypoxia-induced brain damage is typically seen in hypoxic encephalopathy and ischemic stroke secondary to SARS-CoV-2 infection. However, it is important to note that direct damage of the brain by SARS-CoV-2 could also lead to respiratory failure and hypoxia [61]. One of the reasons behind ARDS is the severe inflammation due to the release of an excessive amount of proinflammatory cytokines that could be responsible for tissue damage in the lungs and other organs including the brain [202,231,232]. Severe inflammation was also noted locally in the brain after SARS-CoV-2 invasion due to the production of proinflammatory cytokines by astrocytes and microglia [21]. This also contributes to brain damage. Accordingly, therapies, such as IL-6 receptor monoclonal antibodies, which aim to reduce inflammation, have been used to prevent inflammationdependent complications in COVID-19 patients [233]. 
Severe inflammation in COVID-19 patients, the infection of endothelial cells, and the activation of coagulation cascade could lead to hypercoagulability and disseminated intravascular coagulation (DIC) that is commonly seen in COVID-19 patients (Figure 2) [77-81]. The severe systemic inflammation on hospital admission could predict mortality in COVID-19 patients [87]. Stroke could be a consequence if anticoagulants are not administered [234,235]. A study demonstrated that serial systemic immune inflammation indices (SSIIi), which are determined based on neutrophil, platelet, and lymphocyte counts, are clinically correlated with PCNS events [236]. This implies that SSIIi could be used as a biomarker for many neurological complications including stroke.

Severe immunosuppression could be also implicated in COVID-19 patients with severe disease [237]. Circulating effector T cells were significantly reduced in COVID19 patients [237]. In some patients, IL-6 was elevated but without elevations in other proinflammatory cytokines. It was noted too that blood mononuclear cells are less activated and produce lower levels of cytokines. All of the above suggests that immune responses may be impaired in some COVID-19 patients, which could lead to uncontrolled viral spread and tissue/organ damage including the CNS. Other studies reported an overproduction of proinflammatory cytokines in COVID-19 patients [238]. Moreover, another study found that in severe COVID-19 patients, there is a high level of anti-SARS-CoV-2 spike protein IgG antibodies [239]. This may indicate that antibody-dependent enhancement (ADE) of infection could play a role in mediating the infection of immune cells that express the $\mathrm{Fc}_{\mathrm{c}} \gamma$ receptor for IgG [240,241]. Antibodies against SARS-CoV-2 can also cross-react with antigens in the nervous system causing complications such as GBS [158]. Based on these findings, overactivation of the immune system leads to hyperinflammation, whereas immunosuppression could result in the dissemination of SARS-CoV-2. Both of these mechanisms would eventually cause tissue damage.

\section{Conclusions}

The health care system is posed with a huge challenge of the current COVID-19 pandemic. Several neurological manifestations have been described in COVID-19 patients; however, more research needs to be performed to understand the pathogenic mechanism behind each of these disorders to better treat such patients with suitable drugs and in a timely manner. We believe that some of the available treatment options might potentially lead to a wave of neurological sequelae. Therefore, treatment of COVID-19 patients should consider the existing or the unknown neurological complications that may develop.

Author Contributions: Conceptualization, G.A.S. and H.A.E.; writing-original draft preparation, G.A.S. and H.A.E.; writing-review and editing, K.C.L., M.C.G., M.E., R.A., and H.A.E.; Figures preparation, M.C.G. and H.A.E. All authors have read and agreed to the published version of the manuscript.

Funding: This work received no funding.

Conflicts of Interest: The authors declare no conflict of interest.

\section{References}

1. Zhou, P.; Yang, X.-L.; Wang, X.-G.; Hu, B.; Zhang, L.; Zhang, W.; Si, H.-R.; Zhu, Y.; Li, B.; Huang, C.-L.; et al. A pneumonia outbreak associated with a new coronavirus of probable bat origin. Nature 2020, 579, 270-273. [CrossRef]

2. Yang, P.; Wang, X. COVID-19: A new challenge for human beings. Cell. Mol. Immunol. 2020, 17, 555-557. [CrossRef]

3. Liotta, E.M.; Batra, A.; Clark, J.R.; Shlobin, N.A.; Hoffman, S.C.; Orban, Z.S.; Koralnik, I.J. Frequent neurologic manifestations and encephalopathy-associated morbidity in Covid-19 patients. Ann. Clin. Transl. Neurol. 2020, 7, 2221-2230. [CrossRef]

4. Ahmad, I.; Rathore, F.A. Neurological manifestations and complications of COVID-19: A literature review. J. Clin. Neurosci. 2020, 77, 8-12. [CrossRef] [PubMed]

5. Andalib, S.; Biller, J.; Di Napoli, M.; Moghimi, N.; McCullough, L.D.; Rubinos, C.A.; O’Hana Nobleza, C.; Azarpazhooh, M.R.; Catanese, L.; Elicer, I.; et al. Peripheral Nervous System Manifestations Associated with COVID-19. Curr. Neurol. Neurosci. Rep. 2021, 21, 9. [CrossRef] [PubMed]

6. McGavern, D.B.; Kang, S.S. Illuminating viral infections in the nervous system. Nat. Rev. Immunol. 2011, 11, 318-329. [CrossRef] [PubMed] 
7. Swanson, P.A., 2nd; McGavern, D.B. Viral diseases of the central nervous system. Curr. Opin. Virol. 2015, 11, 44-54. [CrossRef] [PubMed]

8. Gonzalez-Scarano, F.; Tyler, K.L. Molecular pathogenesis of neurotropic viral infections. Ann. Neurol. 1987, 22, 565-574. [CrossRef] [PubMed]

9. Suen, W.W.; Prow, N.A.; Hall, R.A.; Bielefeldt-Ohmann, H. Mechanism of West Nile virus neuroinvasion: A critical appraisal. Viruses 2014, 6, 2796-2825. [CrossRef]

10. Koyuncu, O.O.; Hogue, I.B.; Enquist, L.W. Virus infections in the nervous system. Cell Host Microbe 2013, 13, 379-393. [CrossRef]

11. Ashour, H.M.; Elkhatib, W.F.; Rahman, M.M.; Elshabrawy, H.A. Insights into the Recent 2019 Novel Coronavirus (SARS-CoV-2) in Light of Past Human Coronavirus Outbreaks. Pathogens 2020, 9, 186. [CrossRef]

12. Van der Hoek, L. Human coronaviruses: What do they cause? Antivir. Ther. 2007, 12, 651-658.

13. Cabeca, T.K.; Granato, C.; Bellei, N. Epidemiological and clinical features of human coronavirus infections among different subsets of patients. Influenza Other Respir. Viruses 2013, 7, 1040-1047. [CrossRef] [PubMed]

14. Matoba, Y.; Abiko, C.; Ikeda, T.; Aoki, Y.; Suzuki, Y.; Yahagi, K.; Matsuzaki, Y.; Itagaki, T.; Katsushima, F.; Katsushima, Y.; et al. Detection of the human coronavirus 229E, HKU1, NL63, and OC43 between 2010 and 2013 in Yamagata, Japan. Jpn. J. Infect. Dis. 2015, 68, 138-141. [CrossRef] [PubMed]

15. Drosten, C.; Gunther, S.; Preiser, W.; van der Werf, S.; Brodt, H.R.; Becker, S.; Rabenau, H.; Panning, M.; Kolesnikova, L.; Fouchier, R.A.; et al. Identification of a novel coronavirus in patients with severe acute respiratory syndrome. N. Engl. J. Med. 2003, 348, 1967-1976. [CrossRef] [PubMed]

16. Zaki, A.M.; van Boheemen, S.; Bestebroer, T.M.; Osterhaus, A.D.; Fouchier, R.A. Isolation of a novel coronavirus from a man with pneumonia in Saudi Arabia. N. Engl. J. Med. 2012, 367, 1814-1820. [CrossRef]

17. Zhu, N.; Zhang, D.; Wang, W.; Li, X.; Yang, B.; Song, J.; Zhao, X.; Huang, B.; Shi, W.; Lu, R.; et al. A Novel Coronavirus from Patients with Pneumonia in China, 2019. N. Engl. J. Med. 2020, 382, 727-733. [CrossRef]

18. Zlateva, K.T.; Van Ranst, M. Detection of subgroup B respiratory syncytial virus in the cerebrospinal fluid of a patient with respiratory syncytial virus pneumonia. Pediatr. Infect. Dis. J. 2004, 23, 1065-1066. [CrossRef]

19. Yeh, E.A.; Collins, A.; Cohen, M.E.; Duffner, P.K.; Faden, H. Detection of coronavirus in the central nervous system of a child with acute disseminated encephalomyelitis. Pediatrics 2004, 113, e73-e76. [CrossRef]

20. St-Jean, J.R.; Jacomy, H.; Desforges, M.; Vabret, A.; Freymuth, F.; Talbot, P.J. Human respiratory coronavirus OC43: Genetic stability and neuroinvasion. J. Virol. 2004, 78, 8824-8834. [CrossRef]

21. Li, Y.; Fu, L.; Gonzales, D.M.; Lavi, E. Coronavirus neurovirulence correlates with the ability of the virus to induce proinflammatory cytokine signals from astrocytes and microglia. J. Virol. 2004, 78, 3398-3406. [CrossRef] [PubMed]

22. Rempel, J.D.; Murray, S.J.; Meisner, J.; Buchmeier, M.J. Mouse hepatitis virus neurovirulence: Evidence of a linkage between S glycoprotein expression and immunopathology. Virology 2004, 318, 45-54. [CrossRef]

23. Almqvist, J.; Granberg, T.; Tzortzakakis, A.; Klironomos, S.; Kollia, E.; Ohberg, C.; Martin, R.; Piehl, F.; Ouellette, R.; Ineichen, B.V. Neurological manifestations of coronavirus infections-A systematic review. Ann. Clin. Transl. Neurol. 2020, 7, $2057-2071$. [CrossRef] [PubMed]

24. Murray, R.S.; Brown, B.; Brian, D.; Cabirac, G.F. Detection of coronavirus RNA and antigen in multiple sclerosis brain. Ann. Neurol. 1992, 31, 525-533. [CrossRef]

25. Stewart, J.N.; Mounir, S.; Talbot, P.J. Human coronavirus gene expression in the brains of multiple sclerosis patients. Virology 1992, 191, 502-505. [CrossRef]

26. Arbour, N.; Day, R.; Newcombe, J.; Talbot, P.J. Neuroinvasion by human respiratory coronaviruses. J. Virol. 2000, 74, 8913-8921. [CrossRef]

27. Jacomy, H.; Fragoso, G.; Almazan, G.; Mushynski, W.E.; Talbot, P.J. Human coronavirus OC43 infection induces chronic encephalitis leading to disabilities in BALB/C mice. Virology 2006, 349, 335-346. [CrossRef] [PubMed]

28. Hung, E.C.; Chim, S.S.; Chan, P.K.; Tong, Y.K.; Ng, E.K.; Chiu, R.W.; Leung, C.B.; Sung, J.J.; Tam, J.S.; Lo, Y.M. Detection of SARS coronavirus RNA in the cerebrospinal fluid of a patient with severe acute respiratory syndrome. Clin. Chem. 2003, 49, 2108-2109. [CrossRef]

29. Lau, K.K.; Yu, W.C.; Chu, C.M.; Lau, S.T.; Sheng, B.; Yuen, K.Y. Possible central nervous system infection by SARS coronavirus. Emerg. Infect. Dis. 2004, 10, 342-344. [CrossRef] [PubMed]

30. Ding, Y.; He, L.; Zhang, Q.; Huang, Z.; Che, X.; Hou, J.; Wang, H.; Shen, H.; Qiu, L.; Li, Z.; et al. Organ distribution of severe acute respiratory syndrome (SARS) associated coronavirus (SARS-CoV) in SARS patients: Implications for pathogenesis and virus transmission pathways. J. Pathol. 2004, 203, 622-630. [CrossRef]

31. Glass, W.G.; Subbarao, K.; Murphy, B.; Murphy, P.M. Mechanisms of host defense following severe acute respiratory syndromecoronavirus (SARS-CoV) pulmonary infection of mice. J. Immunol. 2004, 173, 4030-4039. [CrossRef]

32. Li, Y.; Li, H.; Fan, R.; Wen, B.; Zhang, J.; Cao, X.; Wang, C.; Song, Z.; Li, S.; Li, X.; et al. Coronavirus Infections in the Central Nervous System and Respiratory Tract Show Distinct Features in Hospitalized Children. Intervirology 2016, 59, 163-169. [CrossRef] [PubMed]

33. Baig, A.M.; Khaleeq, A.; Ali, U.; Syeda, H. Evidence of the COVID-19 Virus Targeting the CNS: Tissue Distribution, Host-Virus Interaction, and Proposed Neurotropic Mechanisms. ACS Chem. Neurosci. 2020, 11, 995-998. [CrossRef] [PubMed] 
34. Wang, H.Y.; Li, X.L.; Yan, Z.R.; Sun, X.P.; Han, J.; Zhang, B.W. Potential neurological symptoms of COVID-19. Ther. Adv. Neurol. Disord. 2020, 13. [CrossRef] [PubMed]

35. Mao, L.; Jin, H.; Wang, M.; Hu, Y.; Chen, S.; He, Q.; Chang, J.; Hong, C.; Zhou, Y.; Wang, D.; et al. Neurologic Manifestations of Hospitalized Patients with Coronavirus Disease 2019 in Wuhan, China. JAMA Neurol. 2020, 77, 683-690. [CrossRef] [PubMed]

36. Hoffmann, M.; Kleine-Weber, H.; Schroeder, S.; Kruger, N.; Herrler, T.; Erichsen, S.; Schiergens, T.S.; Herrler, G.; Wu, N.H.; Nitsche, A.; et al. SARS-CoV-2 Cell Entry Depends on ACE2 and TMPRSS2 and Is Blocked by a Clinically Proven Protease Inhibitor. Cell 2020, 181, 271-280.e278. [CrossRef] [PubMed]

37. Wang, K.; Chen, W.; Zhang, Z.; Deng, Y.; Lian, J.Q.; Du, P.; Wei, D.; Zhang, Y.; Sun, X.X.; Gong, L.; et al. CD147-spike protein is a novel route for SARS-CoV-2 infection to host cells. Signal. Transduct. Target. Ther. 2020, 5, 283. [CrossRef]

38. Cantuti-Castelvetri, L.; Ojha, R.; Pedro, L.D.; Djannatian, M.; Franz, J.; Kuivanen, S.; van der Meer, F.; Kallio, K.; Kaya, T.; Anastasina, M.; et al. Neuropilin-1 facilitates SARS-CoV-2 cell entry and infectivity. Science 2020, 370, 856-860. [CrossRef] [PubMed]

39. Iadecola, C.; Anrather, J.; Kamel, H. Effects of COVID-19 on the Nervous System. Cell 2020, 183, 16-27.e11. [CrossRef] [PubMed]

40. Paniz-Mondolfi, A.; Bryce, C.; Grimes, Z.; Gordon, R.E.; Reidy, J.; Lednicky, J.; Sordillo, E.M.; Fowkes, M. Central nervous system involvement by severe acute respiratory syndrome coronavirus-2 (SARS-CoV-2). J. Med. Virol. 2020, 92, 699-702. [CrossRef] [PubMed]

41. Moriguchi, T.; Harii, N.; Goto, J.; Harada, D.; Sugawara, H.; Takamino, J.; Ueno, M.; Sakata, H.; Kondo, K.; Myose, N.; et al. A first case of meningitis/encephalitis associated with SARS-Coronavirus-2. Int. J. Infect. Dis. 2020, 94, 55-58. [CrossRef]

42. Huang, Y.H.; Jiang, D.; Huang, J.T. SARS-CoV-2 Detected in Cerebrospinal Fluid by PCR in a Case of COVID-19 Encephalitis. Brain Behav. Immun. 2020, 87, 149. [CrossRef]

43. Serrano, G.E.; Walker, J.E.; Arce, R.; Glass, M.J.; Vargas, D.; Sue, L.I.; Intorcia, A.J.; Nelson, C.M.; Oliver, J.; Papa, J.; et al. Mapping of SARS-CoV-2 Brain Invasion and Histopathology in COVID-19 Disease. medRxiv 2021. [CrossRef]

44. Freij, B.J.; Gebara, B.M.; Tariq, R.; Wang, A.M.; Gibson, J.; El-Wiher, N.; Krasan, G.; Patek, P.M.; Levasseur, K.A.; Amin, M.; et al. Fatal central nervous system co-infection with SARS-CoV-2 and tuberculosis in a healthy child. BMC Pediatr. 2020, $20,429$. [CrossRef]

45. Remmelink, M.; De Mendonca, R.; D’Haene, N.; De Clercq, S.; Verocq, C.; Lebrun, L.; Lavis, P.; Racu, M.L.; Trepant, A.L.; Maris, C.; et al. Unspecific post-mortem findings despite multiorgan viral spread in COVID-19 patients. Crit. Care 2020, $24,495$. [CrossRef]

46. Song, E.; Zhang, C.; Israelow, B.; Lu-Culligan, A.; Prado, A.V.; Skriabine, S.; Lu, P.; Weizman, O.E.; Liu, F.; Dai, Y.; et al. Neuroinvasion of SARS-CoV-2 in human and mouse brain. J. Exp. Med. 2021, 218. [CrossRef]

47. Matschke, J.; Lutgehetmann, M.; Hagel, C.; Sperhake, J.P.; Schroder, A.S.; Edler, C.; Mushumba, H.; Fitzek, A.; Allweiss, L.; Dandri, M.; et al. Neuropathology of patients with COVID-19 in Germany: A post-mortem case series. Lancet Neurol. 2020, 19, 919-929. [CrossRef]

48. Solomon, I.H.; Normandin, E.; Bhattacharyya, S.; Mukerji, S.S.; Keller, K.; Ali, A.S.; Adams, G.; Hornick, J.L.; Padera, R.F., Jr.; Sabeti, P. Neuropathological Features of Covid-19. N. Engl. J. Med. 2020, 383, 989-992. [CrossRef] [PubMed]

49. Toscano, G.; Palmerini, F.; Ravaglia, S.; Ruiz, L.; Invernizzi, P.; Cuzzoni, M.G.; Franciotta, D.; Baldanti, F.; Daturi, R.; Postorino, P.; et al. Guillain-Barre Syndrome Associated with SARS-CoV-2. N. Engl. J. Med. 2020, 382, 2574-2576. [CrossRef] [PubMed]

50. Espindola, O.M.; Siqueira, M.; Soares, C.N.; Lima, M.; Leite, A.; Araujo, A.Q.C.; Brandao, C.O.; Silva, M.T.T. Patients with COVID-19 and neurological manifestations show undetectable SARS-CoV-2 RNA levels in the cerebrospinal fluid. Int. J. Infect. Dis. 2020, 96, 567-569. [CrossRef]

51. Lee, M.H.; Perl, D.P.; Nair, G.; Li, W.; Maric, D.; Murray, H.; Dodd, S.J.; Koretsky, A.P.; Watts, J.A.; Cheung, V.; et al. Microvascular Injury in the Brains of Patients with Covid-19. N. Engl. J. Med. 2021, 384, 481-483. [CrossRef]

52. Jensen, M.P.; Le Quesne, J.; Officer-Jones, L.; Teodosio, A.; Thaventhiran, J.; Ficken, C.; Goddard, M.; Smith, C.; Menon, D.; Allinson, K.S.J. Neuropathological findings in two patients with fatal COVID-19. Neuropathol. Appl. Neurobiol. 2021, 47, 17-25. [CrossRef]

53. Keller, E.; Brandi, G.; Winklhofer, S.; Imbach, L.L.; Kirschenbaum, D.; Frontzek, K.; Steiger, P.; Dietler, S.; Haeberlin, M.; Willms, J.; et al. Large and Small Cerebral Vessel Involvement in Severe COVID-19: Detailed Clinical Workup of a Case Series. Stroke 2020, 51, 3719-3722. [CrossRef]

54. Bihlmaier, K.; Coras, R.; Willam, C.; Grampp, S.; Jabari, S.; Eichhorn, P.; Haller, F.; Kuramatsu, J.; Schwab, S.; Castellanos, I.; et al. Disseminated Multifocal Intracerebral Bleeding Events in Three Coronavirus Disease 2019 Patients on Extracorporeal Membrane Oxygenation As Rescue Therapy. Crit. Care Explor. 2020, 2, e0218. [CrossRef]

55. Bernard-Valnet, R.; Pizzarotti, B.; Anichini, A.; Demars, Y.; Russo, E.; Schmidhauser, M.; Cerutti-Sola, J.; Rossetti, A.O.; Du Pasquier, R. Two patients with acute meningoencephalitis concomitant with SARS-CoV-2 infection. Eur. J. Neurol. 2020, 27, e43-e44. [CrossRef]

56. Ye, M.; Ren, Y.; Lv, T. Encephalitis as a clinical manifestation of COVID-19. Brain Behav. Immun. 2020, 88, 945-946. [CrossRef] [PubMed]

57. Barrantes, F.J. Central Nervous System Targets and Routes for SARS-CoV-2: Current Views and New Hypotheses. ACS Chem. Neurosci. 2020, 11, 2793-2803. [CrossRef] 
58. Stefano, M.L.; Kream, R.M.; Stefano, G.B. A Novel Vaccine Employing Non-Replicating Rabies Virus Expressing Chimeric SARS-CoV-2 Spike Protein Domains: Functional Inhibition of Viral/Nicotinic Acetylcholine Receptor Complexes. Med. Sci. Monit. 2020, 26, e926016. [CrossRef] [PubMed]

59. Puccioni-Sohler, M.; Poton, A.R.; Franklin, M.; Silva, S.J.D.; Brindeiro, R.; Tanuri, A. Current evidence of neurological features, diagnosis, and neuropathogenesis associated with COVID-19. Rev. Soc. Bras. Med. Trop. 2020, 53, e20200477. [CrossRef] [PubMed]

60. Wu, Y.; Xu, X.; Chen, Z.; Duan, J.; Hashimoto, K.; Yang, L.; Liu, C.; Yang, C. Nervous system involvement after infection with COVID-19 and other coronaviruses. Brain Behav. Immun. 2020, 87, 18-22. [CrossRef]

61. Li, Y.C.; Bai, W.Z.; Hashikawa, T. The neuroinvasive potential of SARS-CoV2 may play a role in the respiratory failure of COVID-19 patients. J. Med. Virol. 2020, 92, 552-555. [CrossRef] [PubMed]

62. Pezzini, A.; Padovani, A. Lifting the mask on neurological manifestations of COVID-19. Nat. Rev. Neurol. 2020, 16, 636-644. [CrossRef]

63. Desforges, M.; Le Coupanec, A.; Brison, E.; Meessen-Pinard, M.; Talbot, P.J. Neuroinvasive and neurotropic human respiratory coronaviruses: Potential neurovirulent agents in humans. Adv. Exp. Med. Biol. 2014, 807, 75-96. [CrossRef] [PubMed]

64. Gu, J.; Gong, E.; Zhang, B.; Zheng, J.; Gao, Z.; Zhong, Y.; Zou, W.; Zhan, J.; Wang, S.; Xie, Z.; et al. Multiple organ infection and the pathogenesis of SARS. J. Exp. Med. 2005, 202, 415-424. [CrossRef] [PubMed]

65. Nicholls, J.M.; Butany, J.; Poon, L.L.; Chan, K.H.; Beh, S.L.; Poutanen, S.; Peiris, J.S.; Wong, M. Time course and cellular localization of SARS-CoV nucleoprotein and RNA in lungs from fatal cases of SARS. PLoS Med. 2006, 3, e27. [CrossRef] [PubMed]

66. Spiegel, M.; Schneider, K.; Weber, F.; Weidmann, M.; Hufert, F.T. Interaction of severe acute respiratory syndrome-associated coronavirus with dendritic cells. J. Gen. Virol. 2006, 87, 1953-1960. [CrossRef]

67. Trojanowicz, B.; Ulrich, C.; Kohler, F.; Bode, V.; Seibert, E.; Fiedler, R.; Girndt, M. Monocytic angiotensin-converting enzyme 2 relates to atherosclerosis in patients with chronic kidney disease. Nephrol. Dial. Transplant. 2017, 32, 287-298. [CrossRef] [PubMed]

68. Abassi, Z.; Knaney, Y.; Karram, T.; Heyman, S.N. The Lung Macrophage in SARS-CoV-2 Infection: A Friend or a Foe? Front. Immunol. 2020, 11, 1312. [CrossRef]

69. Bost, P.; Giladi, A.; Liu, Y.; Bendjelal, Y.; Xu, G.; David, E.; Blecher-Gonen, R.; Cohen, M.; Medaglia, C.; Li, H.; et al. Host-Viral Infection Maps Reveal Signatures of Severe COVID-19 Patients. Cell 2020, 181, 1475-1488.e1412. [CrossRef] [PubMed]

70. Bilinska, K.; Jakubowska, P.; Von Bartheld, C.S.; Butowt, R. Expression of the SARS-CoV-2 Entry Proteins, ACE2 and TMPRSS2, in Cells of the Olfactory Epithelium: Identification of Cell Types and Trends with Age. ACS Chem. Neurosci. 2020, 11, 1555-1562. [CrossRef]

71. Brann, D.H.; Tsukahara, T.; Weinreb, C.; Lipovsek, M.; Van den Berge, K.; Gong, B.; Chance, R.; Macaulay, I.C.; Chou, H.J.; Fletcher, R.B.; et al. Non-neuronal expression of SARS-CoV-2 entry genes in the olfactory system suggests mechanisms underlying COVID-19-associated anosmia. Sci. Adv. 2020, 6. [CrossRef]

72. McCray, P.B., Jr.; Pewe, L.; Wohlford-Lenane, C.; Hickey, M.; Manzel, L.; Shi, L.; Netland, J.; Jia, H.P.; Halabi, C.; Sigmund, C.D.; et al. Lethal infection of K18-hACE2 mice infected with severe acute respiratory syndrome coronavirus. J. Virol. 2007, 81, 813-821. [CrossRef]

73. Li, Y.C.; Bai, W.Z.; Hirano, N.; Hayashida, T.; Hashikawa, T. Coronavirus infection of rat dorsal root ganglia: Ultrastructural characterization of viral replication, transfer, and the early response of satellite cells. Virus Res. 2012, 163, 628-635. [CrossRef] [PubMed]

74. Desforges, M.; Le Coupanec, A.; Dubeau, P.; Bourgouin, A.; Lajoie, L.; Dube, M.; Talbot, P.J. Human Coronaviruses and Other Respiratory Viruses: Underestimated Opportunistic Pathogens of the Central Nervous System? Viruses 2019, 12, 14. [CrossRef] [PubMed]

75. Yaghi, S.; Ishida, K.; Torres, J.; Mac Grory, B.; Raz, E.; Humbert, K.; Henninger, N.; Trivedi, T.; Lillemoe, K.; Alam, S.; et al. SARS-CoV-2 and Stroke in a New York Healthcare System. Stroke 2020, 51, 2002-2011. [CrossRef]

76. Lodigiani, C.; Iapichino, G.; Carenzo, L.; Cecconi, M.; Ferrazzi, P.; Sebastian, T.; Kucher, N.; Studt, J.D.; Sacco, C.; Bertuzzi, A.; et al. Venous and arterial thromboembolic complications in COVID-19 patients admitted to an academic hospital in Milan, Italy. Thromb. Res. 2020, 191, 9-14. [CrossRef] [PubMed]

77. Pons, S.; Fodil, S.; Azoulay, E.; Zafrani, L. The vascular endothelium: The cornerstone of organ dysfunction in severe SARS-CoV-2 infection. Crit. Care 2020, 24, 353. [CrossRef]

78. Ranucci, M.; Ballotta, A.; Di Dedda, U.; Bayshnikova, E.; Dei Poli, M.; Resta, M.; Falco, M.; Albano, G.; Menicanti, L. The procoagulant pattern of patients with COVID-19 acute respiratory distress syndrome. J. Thromb. Haemost. 2020, 18, 1747-1751. [CrossRef]

79. Klok, F.A.; Kruip, M.; van der Meer, N.J.M.; Arbous, M.S.; Gommers, D.; Kant, K.M.; Kaptein, F.H.J.; van Paassen, J.; Stals, M.A.M.; Huisman, M.V.; et al. Incidence of thrombotic complications in critically ill ICU patients with COVID-19. Thromb. Res. 2020, 191, 145-147. [CrossRef]

80. Varga, Z.; Flammer, A.J.; Steiger, P.; Haberecker, M.; Andermatt, R.; Zinkernagel, A.S.; Mehra, M.R.; Schuepbach, R.A.; Ruschitzka, F.; Moch, H. Endothelial cell infection and endotheliitis in COVID-19. Lancet 2020, 395, 1417-1418. [CrossRef]

81. Bruggemann, R.; Gietema, H.; Jallah, B.; Ten Cate, H.; Stehouwer, C.; Spaetgens, B. Arterial and venous thromboembolic disease in a patient with COVID-19: A case report. Thromb. Res. 2020, 191, 153-155. [CrossRef] [PubMed]

82. Liu, Y.; Du, X.; Chen, J.; Jin, Y.; Peng, L.; Wang, H.H.X.; Luo, M.; Chen, L.; Zhao, Y. Neutrophil-to-lymphocyte ratio as an independent risk factor for mortality in hospitalized patients with COVID-19. J. Infect. 2020, 81, e6-e12. [CrossRef] [PubMed] 
83. Liu, J.; Li, S.; Liu, J.; Liang, B.; Wang, X.; Wang, H.; Li, W.; Tong, Q.; Yi, J.; Zhao, L.; et al. Longitudinal characteristics of lymphocyte responses and cytokine profiles in the peripheral blood of SARS-CoV-2 infected patients. EBioMedicine 2020, 55, 102763. [CrossRef]

84. Liu, Y.P.; Li, G.M.; He, J.; Liu, Y.; Li, M.; Zhang, R.; Li, Y.L.; Wu, Y.Z.; Diao, B. Combined use of the neutrophil-to-lymphocyte ratio and CRP to predict 7-day disease severity in 84 hospitalized patients with COVID-19 pneumonia: A retrospective cohort study. Ann. Transl. Med. 2020, 8, 635. [CrossRef]

85. Shang, W.; Dong, J.; Ren, Y.; Tian, M.; Li, W.; Hu, J.; Li, Y. The value of clinical parameters in predicting the severity of COVID-19. J. Med. Virol. 2020, 92, 2188-2192. [CrossRef]

86. Wijeratne, T.; Gillard Crewther, S.; Sales, C.; Karimi, L. COVID-19 Pathophysiology Predicts That Ischemic Stroke Occurrence Is an Expectation, Not an Exception-A Systematic Review. Front. Neurol. 2020, 11, 607221. [CrossRef]

87. Fois, A.G.; Paliogiannis, P.; Scano, V.; Cau, S.; Babudieri, S.; Perra, R.; Ruzzittu, G.; Zinellu, E.; Pirina, P.; Carru, C.; et al. The Systemic Inflammation Index on Admission Predicts In-Hospital Mortality in COVID-19 Patients. Molecules 2020, $25,5725$. [CrossRef] [PubMed]

88. Zuo, Y.; Yalavarthi, S.; Shi, H.; Gockman, K.; Zuo, M.; Madison, J.A.; Blair, C.; Weber, A.; Barnes, B.J.; Egeblad, M.; et al. Neutrophil extracellular traps (NETs) as markers of disease severity in COVID-19. medRxiv 2020. [CrossRef]

89. Tomar, B.; Anders, H.J.; Desai, J.; Mulay, S.R. Neutrophils and Neutrophil Extracellular Traps Drive Necroinflammation in COVID-19. Cells 2020, 9, 1383. [CrossRef]

90. Middleton, E.A.; He, X.Y.; Denorme, F.; Campbell, R.A.; Ng, D.; Salvatore, S.P.; Mostyka, M.; Baxter-Stoltzfus, A.; Borczuk, A.C.; Loda, M.; et al. Neutrophil extracellular traps contribute to immunothrombosis in COVID-19 acute respiratory distress syndrome. Blood 2020, 136, 1169-1179. [CrossRef]

91. Medcalf, R.L.; Keragala, C.B.; Myles, P.S. Fibrinolysis and COVID-19: A plasmin paradox. J. Thromb. Haemost. 2020, 18, $2118-2122$. [CrossRef]

92. Zhang, Y.; Cao, W.; Jiang, W.; Xiao, M.; Li, Y.; Tang, N.; Liu, Z.; Yan, X.; Zhao, Y.; Li, T.; et al. Profile of natural anticoagulant, coagulant factor and anti-phospholipid antibody in critically ill COVID-19 patients. J. Thromb. Thrombolysis 2020, 50, 580-586. [CrossRef] [PubMed]

93. Zhang, Y.; Xiao, M.; Zhang, S.; Xia, P.; Cao, W.; Jiang, W.; Chen, H.; Ding, X.; Zhao, H.; Zhang, H.; et al. Coagulopathy and Antiphospholipid Antibodies in Patients with Covid-19. N. Engl. J. Med. 2020, 382, e38. [CrossRef] [PubMed]

94. Aubignat, M.; Godefroy, O. COVID-19 and ischemic stroke: Should we systematically look for lupus anticoagulant and antiphospholipid antibodies? Rev. Neurol. 2020, 176, 505-506. [CrossRef] [PubMed]

95. Akerstrom, S.; Gunalan, V.; Keng, C.T.; Tan, Y.J.; Mirazimi, A. Dual effect of nitric oxide on SARS-CoV replication: Viral RNA production and palmitoylation of the S protein are affected. Virology 2009, 395, 1-9. [CrossRef]

96. Kochi, A.N.; Tagliari, A.P.; Forleo, G.B.; Fassini, G.M.; Tondo, C. Cardiac and arrhythmic complications in patients with COVID-19. J. Cardiovasc. Electrophysiol. 2020, 31, 1003-1008. [CrossRef]

97. Sharifian-Dorche, M.; Huot, P.; Osherov, M.; Wen, D.; Saveriano, A.; Giacomini, P.S.; Antel, J.P.; Mowla, A. Neurological complications of coronavirus infection; a comparative review and lessons learned during the COVID-19 pandemic. J. Neurol. Sci. 2020, 417, 117085. [CrossRef]

98. Wijeratne, T.; Sales, C.A.; Crewther, S.G.; Nguyen, V.; Karimi, L. First Australian Case of Good Recovery of a COVID-19 Patient with Severe Neurological Symptoms Post Prolonged Hospitalization. Cureus 2020, 12, e10366. [CrossRef]

99. Pereira, M.P.; Lima, E.G.; Serrano, C.V., Jr. Viral infections and atherothrombosis: Another caution in the wake of COVID-19? Rev. Assoc. Med. Bras. 2020, 66, 366-369. [CrossRef]

100. Hansson, G.K.; Libby, P.; Tabas, I. Inflammation and plaque vulnerability. J. Intern. Med. 2015, 278, 483-493. [CrossRef]

101. Hermus, L.; Lefrandt, J.D.; Tio, R.A.; Breek, J.C.; Zeebregts, C.J. Carotid plaque formation and serum biomarkers. Atherosclerosis 2010, 213, 21-29. [CrossRef]

102. Anrather, J.; Iadecola, C. Inflammation and Stroke: An Overview. Neurotherapeutics 2016, 13, 661-670. [CrossRef]

103. Iadecola, C.; Anrather, J. The immunology of stroke: From mechanisms to translation. Nat. Med. 2011, 17, 796-808. [CrossRef]

104. Algahtani, H.; Subahi, A.; Shirah, B. Neurological Complications of Middle East Respiratory Syndrome Coronavirus: A Report of Two Cases and Review of the Literature. Case Rep. Neurol. Med. 2016, 2016, 3502683. [CrossRef]

105. Al-Hameed, F.M. Spontaneous intracranial hemorrhage in a patient with Middle East respiratory syndrome corona virus. Saudi Med. J. 2017, 38, 196-200. [CrossRef] [PubMed]

106. Munakomi, S.; Bharati, K. Letter to the Editor Regarding "Acute Hemorrhage After Intracerebral Biopsy in COVID-19 Patients: A Report of 3 Cases". World Neurosurg. 2020, 141, 558. [CrossRef]

107. Phipps, M.S.; Cronin, C.A. Management of acute ischemic stroke. BMJ 2020, 368, 16983. [CrossRef] [PubMed]

108. Salahuddin, H.; Castonguay, A.C.; Zaidi, S.F.; Burgess, R.; Jadhav, A.P.; Jumaa, M.A. Interventional Stroke Care in the Era of COVID-19. Front. Neurol. 2020, 11, 468. [CrossRef] [PubMed]

109. Al Hashmi, A.M.; Ozdemir, A.O.; Shuaib, A.; Al-Jehani, H.; Mansour, O.Y.; Alhazzani, A.; Aladhem, F.; Farhoudi, M.; John, S.; Saqqur, M. Current Recommendations for the Management of Stroke Patients in the Middle East in the Era of COVID-19 Pandemic; Statement from the MENA SINO. J. Stroke Cerebrovasc. Dis. 2020, 29, 105181. [CrossRef] [PubMed]

110. Ford, T.; Curiale, G.; Nguyen, T.N.; Aparicio, H.; Hamlyn, E.K.; Gangadhara, S.; Cervantes-Arslanian, A.M.; Greer, D.; Romero, J.R.; Shulman, J.G. Optimization of resources and modifications in acute ischemic stroke care in response to the global COVID-19 pandemic. J. Stroke Cerebrovasc. Dis. 2020, 29, 104980. [CrossRef] [PubMed] 
111. Akima, S.; McLintock, C.; Hunt, B.J. RE: ISTH interim guidance to recognition and management of coagulopathy in COVID-19. J. Thromb. Haemost. 2020, 18, 2057-2058. [CrossRef] [PubMed]

112. Moores, L.K.; Tritschler, T.; Brosnahan, S.; Carrier, M.; Collen, J.F.; Doerschug, K.; Holley, A.B.; Jimenez, D.; Le Gal, G.; Rali, P.; et al. Prevention, Diagnosis, and Treatment of VTE in Patients with Coronavirus Disease 2019: CHEST Guideline and Expert Panel Report. Chest 2020, 158, 1143-1163. [CrossRef]

113. Bikdeli, B.; Madhavan, M.V.; Jimenez, D.; Chuich, T.; Dreyfus, I.; Driggin, E.; Nigoghossian, C.; Ageno, W.; Madjid, M.; Guo, Y.; et al. COVID-19 and Thrombotic or Thromboembolic Disease: Implications for Prevention, Antithrombotic Therapy, and Follow-Up: JACC State-of-the-Art Review. J. Am. Coll. Cardiol. 2020, 75, 2950-2973. [CrossRef]

114. Valderrama, E.V.; Humbert, K.; Lord, A.; Frontera, J.; Yaghi, S. Severe Acute Respiratory Syndrome Coronavirus 2 Infection and Ischemic Stroke. Stroke 2020, 51, e124-e127. [CrossRef] [PubMed]

115. Oxley, T.J.; Mocco, J.; Majidi, S.; Kellner, C.P.; Shoirah, H.; Singh, I.P.; De Leacy, R.A.; Shigematsu, T.; Ladner, T.R.; Yaeger, K.A.; et al. Large-Vessel Stroke as a Presenting Feature of Covid-19 in the Young. N. Engl. J. Med. 2020, 382, e60. [CrossRef] [PubMed]

116. Meyfroidt, G.; Kurtz, P.; Sonneville, R. Critical care management of infectious meningitis and encephalitis. Intensive Care Med. 2020, 46, 192-201. [CrossRef] [PubMed]

117. Pennisi, M.; Lanza, G.; Falzone, L.; Fisicaro, F.; Ferri, R.; Bella, R. SARS-CoV-2 and the Nervous System: From Clinical Features to Molecular Mechanisms. Int. J. Mol. Sci. 2020, 21, 5475. [CrossRef] [PubMed]

118. Duong, L.; Xu, P.; Liu, A. Meningoencephalitis without respiratory failure in a young female patient with COVID-19 infection in Downtown Los Angeles, early April 2020. Brain Behav. Immun. 2020, 87, 33. [CrossRef] [PubMed]

119. Benameur, K.; Agarwal, A.; Auld, S.C.; Butters, M.P.; Webster, A.S.; Ozturk, T.; Howell, J.C.; Bassit, L.C.; Velasquez, A.; Schinazi, R.F.; et al. Encephalopathy and Encephalitis Associated with Cerebrospinal Fluid Cytokine Alterations and Coronavirus Disease, Atlanta, Georgia, USA, 2020. Emerg. Infect. Dis. 2020, 26, 2016-2021. [CrossRef] [PubMed]

120. Yu, H.; Sun, T.; Feng, J. Complications and Pathophysiology of COVID-19 in the Nervous System. Front. Neurol. 2020, $11,573421$. [CrossRef] [PubMed]

121. Parsons, T.; Banks, S.; Bae, C.; Gelber, J.; Alahmadi, H.; Tichauer, M. COVID-19-associated acute disseminated encephalomyelitis (ADEM). J. Neurol. 2020, 267, 2799-2802. [CrossRef]

122. Reichard, R.R.; Kashani, K.B.; Boire, N.A.; Constantopoulos, E.; Guo, Y.; Lucchinetti, C.F. Neuropathology of COVID-19: A spectrum of vascular and acute disseminated encephalomyelitis (ADEM)-like pathology. Acta Neuropathol. 2020, 140, 1-6. [CrossRef] [PubMed]

123. Chen, T.; Wu, D.; Chen, H.; Yan, W.; Yang, D.; Chen, G.; Ma, K.; Xu, D.; Yu, H.; Wang, H.; et al. Clinical characteristics of 113 deceased patients with coronavirus disease 2019: Retrospective study. BMJ 2020, 368, m1091. [CrossRef] [PubMed]

124. Nath, A.; Smith, B. Neurological complications of COVID-19: From bridesmaid to bride. Arq. Neuropsiquiatr. 2020, 78, 459-460. [CrossRef] [PubMed]

125. Filatov, A.; Sharma, P.; Hindi, F.; Espinosa, P.S. Neurological Complications of Coronavirus Disease (COVID-19): Encephalopathy. Cureus 2020, 12, e7352. [CrossRef] [PubMed]

126. Espinosa, P.S.; Rizvi, Z.; Sharma, P.; Hindi, F.; Filatov, A. Neurological Complications of Coronavirus Disease (COVID-19): Encephalopathy, MRI Brain and Cerebrospinal Fluid Findings: Case 2. Cureus 2020, 12, e7930. [CrossRef]

127. Virhammar, J.; Kumlien, E.; Fallmar, D.; Frithiof, R.; Jackmann, S.; Skold, M.K.; Kadir, M.; Frick, J.; Lindeberg, J.; Olivero-Reinius, H.; et al. Acute necrotizing encephalopathy with SARS-CoV-2 RNA confirmed in cerebrospinal fluid. Neurology 2020, 95, 445-449. [CrossRef]

128. Radmanesh, A.; Derman, A.; Ishida, K. COVID-19-associated delayed posthypoxic necrotizing leukoencephalopathy. J. Neurol. Sci. 2020, 415, 116945. [CrossRef] [PubMed]

129. Poyiadji, N.; Shahin, G.; Noujaim, D.; Stone, M.; Patel, S.; Griffith, B. COVID-19-associated Acute Hemorrhagic Necrotizing Encephalopathy: Imaging Features. Radiology 2020, 296, E119-E120. [CrossRef] [PubMed]

130. Kennedy, M.; Helfand, B.K.I.; Gou, R.Y.; Gartaganis, S.L.; Webb, M.; Moccia, J.M.; Bruursema, S.N.; Dokic, B.; McCulloch, B.; Ring, H.; et al. Delirium in Older Patients with COVID-19 Presenting to the Emergency Department. JAMA Netw. Open 2020, 3, e2029540. [CrossRef]

131. Pun, B.T.; Badenes, R.; Heras La Calle, G.; Orun, O.M.; Chen, W.; Raman, R.; Simpson, B.K.; Wilson-Linville, S.; Hinojal Olmedillo, B.; Vallejo de la Cueva, A.; et al. Prevalence and risk factors for delirium in critically ill patients with COVID-19 (COVID-D): A multicentre cohort study. Lancet Respir. Med. 2021, 9, 239-250. [CrossRef]

132. Cag, Y.; Erdem, H.; Leib, S.; Defres, S.; Kaya, S.; Larsen, L.; Poljak, M.; Ozturk-Engin, D.; Barsic, B.; Argemi, X.; et al. Managing atypical and typical herpetic central nervous system infections: Results of a multinational study. Clin. Microbiol. Infect. 2016, 22, 568.e9. [CrossRef] [PubMed]

133. Asadi-Pooya, A.A. Seizures associated with coronavirus infections. Seizure 2020, 79, 49-52. [CrossRef] [PubMed]

134. Vollono, C.; Rollo, E.; Romozzi, M.; Frisullo, G.; Servidei, S.; Borghetti, A.; Calabresi, P. Focal status epilepticus as unique clinical feature of COVID-19: A case report. Seizure 2020, 78, 109-112. [CrossRef]

135. Hepburn, M.; Mullaguri, N.; George, P.; Hantus, S.; Punia, V.; Bhimraj, A.; Newey, C.R. Acute Symptomatic Seizures in Critically Ill Patients with COVID-19: Is There an Association? Neurocrit. Care 2021, 34, 139-143. [CrossRef] [PubMed] 
136. Scullen, T.; Keen, J.; Mathkour, M.; Dumont, A.S.; Kahn, L. Coronavirus 2019 (COVID-19)-Associated Encephalopathies and Cerebrovascular Disease: The New Orleans Experience. World Neurosurg. 2020, 141, e437-e446. [CrossRef] [PubMed]

137. Lyons, S.; O'Kelly, B.; Woods, S.; Rowan, C.; Brady, D.; Sheehan, G.; Smyth, S. Seizure with CSF lymphocytosis as a presenting feature of COVID-19 in an otherwise healthy young man. Seizure 2020, 80, 113-114. [CrossRef]

138. Elgamasy, S.; Kamel, M.G.; Ghozy, S.; Khalil, A.; Morra, M.E.; Islam, S.M.S. First case of focal epilepsy associated with SARScoronavirus-2. J. Med. Virol. 2020, 92, 2238-2242. [CrossRef] [PubMed]

139. Abdulsalam, M.A.; Abdulsalam, A.J.; Shehab, D. Generalized status epilepticus as a possible manifestation of COVID-19. Acta Neurol. Scand. 2020, 142, 297-298. [CrossRef] [PubMed]

140. Somani, S.; Pati, S.; Gaston, T.; Chitlangia, A.; Agnihotri, S. De Novo Status Epilepticus in patients with COVID-19. Ann. Clin. Transl. Neurol. 2020, 7, 1240-1244. [CrossRef]

141. Ashraf, M.; Sajed, S. Seizures Related to Coronavirus Disease (COVID-19): Case Series and Literature Review. Cureus 2020, 12, e9378. [CrossRef] [PubMed]

142. Bhatta, S.; Sayed, A.; Ranabhat, B.; Bhatta, R.K.; Acharya, Y. New-Onset Seizure as the Only Presentation in a Child with COVID-19. Cureus 2020, 12, e8820. [CrossRef] [PubMed]

143. Saeed, A.; Shorafa, E. Status epilepticus as a first presentation of COVID-19 infection in a 3 years old boy; Case report and review the literature. IDCases 2020, 22, e00942. [CrossRef] [PubMed]

144. Lu, L.; Xiong, W.; Liu, D.; Liu, J.; Yang, D.; Li, N.; Mu, J.; Guo, J.; Li, W.; Wang, G.; et al. New onset acute symptomatic seizure and risk factors in coronavirus disease 2019: A retrospective multicenter study. Epilepsia 2020, 61, e49-e53. [CrossRef] [PubMed]

145. von Hentig, N. Repositioning HIV protease inhibitors and nucleos(t)ide RNA polymerase inhibitors for the treatment of SARS-CoV-2 infection and COVID-19. Eur. J. Clin. Pharmacol. 2021. [CrossRef] [PubMed]

146. Yeh, R.F.; Gaver, V.E.; Patterson, K.B.; Rezk, N.L.; Baxter-Meheux, F.; Blake, M.J.; Eron, J.J., Jr.; Klein, C.E.; Rublein, J.C.; Kashuba, A.D. Lopinavir/ritonavir induces the hepatic activity of cytochrome P450 enzymes CYP2C9, CYP2C19, and CYP1A2 but inhibits the hepatic and intestinal activity of CYP3A as measured by a phenotyping drug cocktail in healthy volunteers. J. Acquir. Immune Defic. Syndr. 2006, 42, 52-60. [CrossRef] [PubMed]

147. Van der Lee, M.J.; Dawood, L.; ter Hofstede, H.J.; de Graaff-Teulen, M.J.; van Ewijk-Beneken Kolmer, E.W.; Caliskan-Yassen, N.; Koopmans, P.P.; Burger, D.M. Lopinavir/ritonavir reduces lamotrigine plasma concentrations in healthy subjects. Clin. Pharmacol. Ther. 2006, 80, 159-168. [CrossRef] [PubMed]

148. Firat, O.; Yalcin, N.; Demirkan, K. COVID-19 \& antiepileptic drugs: Should we pay attention? Seizure 2020, 80, 240-241. [CrossRef]

149. Bahcecioglu, O.F.; Gok, S.; Durmus, M. Is it safe to use remdesivir in combination with a combined p-glycoprotein and CYP3A4 inhibitor? Eur. J. Hosp. Pharm. 2021, 28, e6. [CrossRef] [PubMed]

150. Asadi-Pooya, A.A.; Attar, A.; Moghadami, M.; Karimzadeh, I. Management of COVID-19 in people with epilepsy: Drug considerations. Neurol. Sci. 2020, 41, 2005-2011. [CrossRef]

151. Butt, I.; Sawlani, V.; Geberhiwot, T. Prolonged confusional state as first manifestation of COVID-19. Ann. Clin. Transl. Neurol. 2020, 7, 1450-1452. [CrossRef]

152. Chen, N.; Zhou, M.; Dong, X.; Qu, J.; Gong, F.; Han, Y.; Qiu, Y.; Wang, J.; Liu, Y.; Wei, Y.; et al. Epidemiological and clinical characteristics of 99 cases of 2019 novel coronavirus pneumonia in Wuhan, China: A descriptive study. Lancet 2020, 395, 507-513. [CrossRef]

153. Helms, J.; Kremer, S.; Merdji, H.; Schenck, M.; Severac, F.; Clere-Jehl, R.; Studer, A.; Radosavljevic, M.; Kummerlen, C.; Monnier, A.; et al. Delirium and encephalopathy in severe COVID-19: A cohort analysis of ICU patients. Crit. Care 2020, 24, 491. [CrossRef]

154. Andrade, G.; Simoes do Couto, F.; Camara-Pestana, L. Recommendations about the Use of Psychotropic Medications during the COVID-19 Pandemic. Acta Med. Port. 2020, 33, 693-702. [CrossRef]

155. Sabe, M.; Dorsaz, O.; Huguelet, P.; Kaiser, S. Toxicity of psychotropic drugs in patients with COVID-19: A systematic review. Gen. Hosp. Psychiatry 2021, 70, 1-9. [CrossRef]

156. Plasencia-Garcia, B.O.; Rodriguez-Menendez, G.; Rico-Rangel, M.I.; Rubio-Garcia, A.; Torello-Iserte, J.; Crespo-Facorro, B. Drug-drug interactions between COVID-19 treatments and antipsychotics drugs: Integrated evidence from 4 databases and a systematic review. Psychopharmacology 2021, 238, 329-340. [CrossRef]

157. Nguyen, T.P.; Taylor, R.S. Guillain Barre Syndrome. In StatPearls; StatPearls Publishing: Treasure Island, FL, USA, 2021.

158. Rahimi, K. Guillain-Barre syndrome during COVID-19 pandemic: An overview of the reports. Neurol. Sci. 2020, 41, $3149-3156$. [CrossRef] [PubMed]

159. Tiet, M.Y.; AlShaikh, N. Guillain-Barre syndrome associated with COVID-19 infection: A case from the UK. BMJ Case Rep. $2020,13$. [CrossRef] [PubMed]

160. Sancho-Saldana, A.; Lambea-Gil, A.; Liesa, J.L.C.; Caballo, M.R.B.; Garay, M.H.; Celada, D.R.; Serrano-Ponz, M. Guillain-Barre syndrome associated with leptomeningeal enhancement following SARS-CoV-2 infection. Clin. Med. 2020, 20, e93-e94. [CrossRef] [PubMed]

161. Tatu, L.; Nono, S.; Gracio, S.; Kocer, S. Guillain-Barre syndrome in the COVID-19 era: Another occasional cluster? J. Neurol. 2020. [CrossRef]

162. Caress, J.B.; Castoro, R.J.; Simmons, Z.; Scelsa, S.N.; Lewis, R.A.; Ahlawat, A.; Narayanaswami, P. COVID-19-associated Guillain-Barre syndrome: The early pandemic experience. Muscle Nerve 2020, 62, 485-491. [CrossRef] 
163. Zhao, H.; Shen, D.; Zhou, H.; Liu, J.; Chen, S. Guillain-Barre syndrome associated with SARS-CoV-2 infection: Causality or coincidence? Lancet Neurol. 2020, 19, 383-384. [CrossRef]

164. Gupta, A.; Paliwal, V.K.; Garg, R.K. Is COVID-19-related Guillain-Barre syndrome different? Brain Behav. Immun. 2020, 87, 177-178. [CrossRef]

165. Gutierrez-Ortiz, C.; Mendez-Guerrero, A.; Rodrigo-Rey, S.; San Pedro-Murillo, E.; Bermejo-Guerrero, L.; Gordo-Manas, R.; de Aragon-Gomez, F.; Benito-Leon, J. Miller Fisher syndrome and polyneuritis cranialis in COVID-19. Neurology 2020, 95, e601-e605. [CrossRef]

166. Lascano, A.M.; Epiney, J.B.; Coen, M.; Serratrice, J.; Bernard-Valnet, R.; Lalive, P.H.; Kuntzer, T.; Hubers, A. SARS-CoV-2 and Guillain-Barre syndrome: AIDP variant with a favourable outcome. Eur. J. Neurol. 2020, 27, 1751-1753. [CrossRef] [PubMed]

167. Assini, A.; Benedetti, L.; Di Maio, S.; Schirinzi, E.; Del Sette, M. Correction to: New clinical manifestation of COVID-19 related Guillain-Barre syndrome highly responsive to intravenous immunoglobulins: Two Italian cases. Neurol. Sci. 2020, $41,2307$. [CrossRef] [PubMed]

168. Khanlou, H.; Valdes-Sueiras, M.; Farthing, C. Peripheral Neuropathy Induced by Lopinavir-Saquinavir-Ritonavir Combination Therapy in an HIV-Infected Patient. J. Int. Assoc. Physicians AIDS Care 2007, 6, 155. [CrossRef]

169. Ellis, R.J.; Marquie-Beck, J.; Delaney, P.; Alexander, T.; Clifford, D.B.; McArthur, J.C.; Simpson, D.M.; Ake, C.; Collier, A.C.; Gelman, B.B.; et al. Human immunodeficiency virus protease inhibitors and risk for peripheral neuropathy. Ann. Neurol. 2008, 64, 566-572. [CrossRef]

170. Madia, F.; Merico, B.; Primiano, G.; Cutuli, S.L.; De Pascale, G.; Servidei, S. Acute myopathic quadriplegia in patients with COVID-19 in the intensive care unit. Neurology 2020, 95, 492-494. [CrossRef] [PubMed]

171. Tankisi, H.; Tankisi, A.; Harbo, T.; Markvardsen, L.K.; Andersen, H.; Pedersen, T.H. Critical illness myopathy as a consequence of Covid-19 infection. Clin. Neurophysiol. 2020, 131, 1931-1932. [CrossRef] [PubMed]

172. Costamagna, G.; Abati, E.; Bresolin, N.; Comi, G.P.; Corti, S. Management of patients with neuromuscular disorders at the time of the SARS-CoV-2 pandemic. J. Neurol. 2020. [CrossRef] [PubMed]

173. Sharifian-Dorche, M.; Sahraian, M.A.; Fadda, G.; Osherov, M.; Sharifian-Dorche, A.; Karaminia, M.; Saveriano, A.W.; La Piana, R.; Antel, J.P.; Giacomini, P.S. COVID-19 and disease-modifying therapies in patients with demyelinating diseases of the central nervous system: A systematic review. Mult. Scler. Relat. Disord. 2021, 50, 102800. [CrossRef]

174. Guidon, A.C.; Amato, A.A. COVID-19 and neuromuscular disorders. Neurology 2020, 94, 959-969. [CrossRef] [PubMed]

175. Salik, I.; Rodhouse, H.B.; Barst, S. Myasthenic crisis in the setting of Coronavirus Disease 2019 (COVID-19). J. Clin. Anesth. 2020, 67, 110001. [CrossRef] [PubMed]

176. Jacob, S.; Muppidi, S.; Guidon, A.; Guptill, J.; Hehir, M.; Howard, J.F.; Illa, I.; Mantegazza, R.; Murai, H.; Utsugisawa, K.; et al. Guidance for the management of myasthenia gravis (MG) and Lambert-Eaton myasthenic syndrome (LEMS) during the COVID-19 pandemic. J. Neurol. Sci. 2020, 412, 116803. [CrossRef] [PubMed]

177. Koc, G.; Odabasi, Z.; Tan, E. Myasthenic Syndrome Caused by Hydroxychloroquine Used for COVID-19 Prophylaxis. J. Clin. Neuromuscul. Dis. 2020, 22, 60-62. [CrossRef] [PubMed]

178. Delly, F.; Syed, M.J.; Lisak, R.P.; Zutshi, D. Myasthenic crisis in COVID-19. J. Neurol. Sci. 2020, 414, 116888. [CrossRef] [PubMed]

179. Siddiqi, Z.A.; Khan, W.; Hussain, F.S. Rituximab in Myasthenia Gravis-Where do we stand? Expert Opin. Biol. Ther. 2021. [CrossRef]

180. Dalakas, M.C. Progress in the therapy of myasthenia gravis: Getting closer to effective targeted immunotherapies. Curr. Opin. Neurol. 2020, 33, 545-552. [CrossRef]

181. Wang, F.; Kream, R.M.; Stefano, G.B. Long-Term Respiratory and Neurological Sequelae of COVID-19. Med. Sci. Monit. 2020, 26, e928996. [CrossRef]

182. Lukiw, W.J.; Pogue, A.; Hill, J.M. SARS-CoV-2 Infectivity and Neurological Targets in the Brain. Cell. Mol. Neurobiol. 2020. [CrossRef] [PubMed]

183. Kempuraj, D.; Selvakumar, G.P.; Ahmed, M.E.; Raikwar, S.P.; Thangavel, R.; Khan, A.; Zaheer, S.A.; Iyer, S.S.; Burton, C.; James, D.; et al. COVID-19, Mast Cells, Cytokine Storm, Psychological Stress, and Neuroinflammation. Neuroscientist 2020, 26, 402-414 [CrossRef] [PubMed]

184. Zanin, L.; Saraceno, G.; Panciani, P.P.; Renisi, G.; Signorini, L.; Migliorati, K.; Fontanella, M.M. SARS-CoV-2 can induce brain and spine demyelinating lesions. Acta Neurochir. 2020, 162, 1491-1494. [CrossRef]

185. Peyrin-Biroulet, L.; Danese, S. More on Covid-19 in Immune-Mediated Inflammatory Diseases. N. Engl. J. Med. 2020, $383,796$. [CrossRef]

186. Sormani, M.P. An Italian programme for COVID-19 infection in multiple sclerosis. Lancet Neurol. 2020, 19, 481-482. [CrossRef]

187. Fuchs, V.; Kutza, M.; Wischnewski, S.; Deigendesch, N.; Lutz, L.; Kulsvehagen, L.; Ricken, G.; Kappos, L.; Tzankov, A.; Hametner, S.; et al. Presence of SARS-CoV-2 Transcripts in the Choroid Plexus of MS and Non-MS Patients with COVID-19. Neurol. Neuroimmunol. Neuroinflamm. 2021, 8. [CrossRef]

188. Sochocka, M.; Zwolinska, K.; Leszek, J. The Infectious Etiology of Alzheimer's Disease. Curr. Neuropharmacol. 2017, 15, 996-1009. [CrossRef] [PubMed]

189. Chen, X.; Laurent, S.; Onur, O.A.; Kleineberg, N.N.; Fink, G.R.; Schweitzer, F.; Warnke, C. A systematic review of neurological symptoms and complications of COVID-19. J. Neurol. 2021, 268, 392-402. [CrossRef] [PubMed] 
190. Krajcovicova, L.; Klobusiakova, P.; Rektorova, I. Gray Matter Changes in Parkinson's and Alzheimer's Disease and Relation to Cognition. Curr. Neurol. Neurosci. Rep. 2019, 19, 85. [CrossRef]

191. Sulzer, D.; Antonini, A.; Leta, V.; Nordvig, A.; Smeyne, R.J.; Goldman, J.E.; Al-Dalahmah, O.; Zecca, L.; Sette, A.; Bubacco, L.; et al. COVID-19 and possible links with Parkinson's disease and parkinsonism: From bench to bedside. NPJ Parkinsons Dis. 2020, 6, 18. [CrossRef]

192. McAlpine, L.S.; Fesharaki-Zadeh, A.; Spudich, S. Coronavirus disease 2019 and neurodegenerative disease: What will the future bring? Curr. Opin. Psychiatry 2021, 34, 177-185. [CrossRef]

193. Campiglio, L.; Priori, A. Neurological symptoms in acute COVID-19 infected patients: A survey among Italian physicians. PLoS ONE 2020, 15, e0238159. [CrossRef] [PubMed]

194. Karadas, O.; Ozturk, B.; Sonkaya, A.R. A prospective clinical study of detailed neurological manifestations in patients with COVID-19. Neurol. Sci. 2020, 41, 1991-1995. [CrossRef] [PubMed]

195. Lai, C.C.; Ko, W.C.; Lee, P.I.; Jean, S.S.; Hsueh, P.R. Extra-respiratory manifestations of COVID-19. Int. J. Antimicrob. Agents 2020, 56, 106024. [CrossRef] [PubMed]

196. Liu, K.; Pan, M.; Xiao, Z.; Xu, X. Neurological manifestations of the coronavirus (SARS-CoV-2) pandemic 2019-2020. J. Neurol. Neurosurg. Psychiatry 2020, 91, 669-670. [CrossRef]

197. Singh, J.; Ali, A. Headache as the Presenting Symptom in 2 Patients with COVID-19 and a History of Migraine: 2 Case Reports. Headache 2020, 60, 1773-1776. [CrossRef]

198. Bolay, H.; Gul, A.; Baykan, B. COVID-19 is a Real Headache! Headache 2020, 60, 1415-1421. [CrossRef]

199. Vacchiano, V.; Riguzzi, P.; Volpi, L.; Tappata, M.; Avoni, P.; Rizzo, G.; Guerra, L.; Zaccaroni, S.; Cortelli, P.; Michelucci, R.; et al. Early neurological manifestations of hospitalized COVID-19 patients. Neurol. Sci. 2020, 41, 2029-2031. [CrossRef] [PubMed]

200. Yang, X.; Yu, Y.; Xu, J.; Shu, H.; Xia, J.; Liu, H.; Wu, Y.; Zhang, L.; Yu, Z.; Fang, M.; et al. Clinical course and outcomes of critically ill patients with SARS-CoV-2 pneumonia in Wuhan, China: A single-centered, retrospective, observational study. Lancet Respir. Med. 2020, 8, 475-481. [CrossRef]

201. Tian, S.; Hu, N.; Lou, J.; Chen, K.; Kang, X.; Xiang, Z.; Chen, H.; Wang, D.; Liu, N.; Liu, D.; et al. Characteristics of COVID-19 infection in Beijing. J. Infect. 2020, 80, 401-406. [CrossRef]

202. Huang, C.; Wang, Y.; Li, X.; Ren, L.; Zhao, J.; Hu, Y.; Zhang, L.; Fan, G.; Xu, J.; Gu, X.; et al. Clinical features of patients infected with 2019 novel coronavirus in Wuhan, China. Lancet 2020, 395, 497-506. [CrossRef]

203. Choi, W.S.; Kang, C.I.; Kim, Y.; Choi, J.P.; Joh, J.S.; Shin, H.S.; Kim, G.; Peck, K.R.; Chung, D.R.; Kim, H.O.; et al. Clinical Presentation and Outcomes of Middle East Respiratory Syndrome in the Republic of Korea. Infect. Chemother. 2016, 48, 118-126. [CrossRef] [PubMed]

204. Kim, E.S.; Chin, B.S.; Kang, C.K.; Kim, N.J.; Kang, Y.M.; Choi, J.P.; Oh, D.H.; Kim, J.H.; Koh, B.; Kim, S.E.; et al. Clinical Course and Outcomes of Patients with Severe Acute Respiratory Syndrome Coronavirus 2 Infection: A Preliminary Report of the First 28 Patients from the Korean Cohort Study on COVID-19. J. Korean Med. Sci. 2020, 35, e142. [CrossRef] [PubMed]

205. Belvis, R. Headaches During COVID-19: My Clinical Case and Review of the Literature. Headache 2020, 60, 1422-1426. [CrossRef] [PubMed]

206. Caronna, E.; Ballve, A.; Llaurado, A.; Gallardo, V.J.; Ariton, D.M.; Lallana, S.; Lopez Maza, S.; Olive Gadea, M.; Quibus, L.; Restrepo, J.L.; et al. Headache: A striking prodromal and persistent symptom, predictive of COVID-19 clinical evolution. Cephalalgia 2020, 40, 1410-1421. [CrossRef]

207. Wang, D.; Hu, B.; Hu, C.; Zhu, F.; Liu, X.; Zhang, J.; Wang, B.; Xiang, H.; Cheng, Z.; Xiong, Y.; et al. Clinical Characteristics of 138 Hospitalized Patients with 2019 Novel Coronavirus-Infected Pneumonia in Wuhan, China. JAMA 2020, 323, 1061-1069. [CrossRef]

208. Sun, L.; Shen, L.; Fan, J.; Gu, F.; Hu, M.; An, Y.; Zhou, Q.; Fan, H.; Bi, J. Clinical features of patients with coronavirus disease 2019 from a designated hospital in Beijing, China. J. Med. Virol. 2020, 92, 2055-2066. [CrossRef] [PubMed]

209. Kong, Z.; Wang, J.; Li, T.; Zhang, Z.; Jian, J. 2019 novel coronavirus pneumonia with onset of dizziness: A case report. Ann. Transl. Med. 2020, 8, 506. [CrossRef]

210. Tsai, S.T.; Lu, M.K.; San, S.; Tsai, C.H. The Neurologic Manifestations of Coronavirus Disease 2019 Pandemic: A Systemic Review. Front. Neurol. 2020, 11, 498. [CrossRef]

211. Harapan, B.N.; Yoo, H.J. Neurological symptoms, manifestations, and complications associated with severe acute respiratory syndrome coronavirus 2 (SARS-CoV-2) and coronavirus disease 19 (COVID-19). J. Neurol. 2021. [CrossRef] [PubMed]

212. Pitscheider, L.; Karolyi, M.; Burkert, F.R.; Helbok, R.; Wanschitz, J.V.; Horlings, C.; Pawelka, E.; Omid, S.; Traugott, M.; Seitz, T.; et al. Muscle involvement in SARS-CoV-2 infection. Eur. J. Neurol. 2020. [CrossRef] [PubMed]

213. Cooper, K.W.; Brann, D.H.; Farruggia, M.C.; Bhutani, S.; Pellegrino, R.; Tsukahara, T.; Weinreb, C.; Joseph, P.V.; Larson, E.D.; Parma, V.; et al. COVID-19 and the Chemical Senses: Supporting Players Take Center Stage. Neuron 2020, 107, 219-233. [CrossRef] [PubMed]

214. Giacomelli, A.; Pezzati, L.; Conti, F.; Bernacchia, D.; Siano, M.; Oreni, L.; Rusconi, S.; Gervasoni, C.; Ridolfo, A.L.; Rizzardini, G.; et al. Self-reported Olfactory and Taste Disorders in Patients with Severe Acute Respiratory Coronavirus 2 Infection: A Cross-sectional Study. Clin. Infect. Dis. 2020, 71, 889-890. [CrossRef] [PubMed] 
215. Beltran-Corbellini, A.; Chico-Garcia, J.L.; Martinez-Poles, J.; Rodriguez-Jorge, F.; Natera-Villalba, E.; Gomez-Corral, J.; GomezLopez, A.; Monreal, E.; Parra-Diaz, P.; Cortes-Cuevas, J.L.; et al. Acute-onset smell and taste disorders in the context of COVID-19: A pilot multicentre polymerase chain reaction based case-control study. Eur. J. Neurol. 2020, 27, 1738-1741. [CrossRef]

216. Lechien, J.R.; Chiesa-Estomba, C.M.; Cabaraux, P.; Mat, Q.; Huet, K.; Harmegnies, B.; Horoi, M.; Le Bon, S.D.; Rodriguez, A.; Dequanter, D.; et al. Features of Mild-to-Moderate COVID-19 Patients with Dysphonia. J. Voice 2020. [CrossRef] [PubMed]

217. Mehraeen, E.; Behnezhad, F.; Salehi, M.A.; Noori, T.; Harandi, H.; SeyedAlinaghi, S. Olfactory and gustatory dysfunctions due to the coronavirus disease (COVID-19): A review of current evidence. Eur. Arch. Otorhinolaryngol. 2021, 278, 307-312. [CrossRef]

218. Lechien, J.R.; Chiesa-Estomba, C.M.; De Siati, D.R.; Horoi, M.; Le Bon, S.D.; Rodriguez, A.; Dequanter, D.; Blecic, S.; El Afia, F.; Distinguin, L.; et al. Olfactory and gustatory dysfunctions as a clinical presentation of mild-to-moderate forms of the coronavirus disease (COVID-19): A multicenter European study. Eur. Arch. Otorhinolaryngol. 2020, 277, 2251-2261. [CrossRef]

219. Benezit, F.; Le Turnier, P.; Declerck, C.; Paille, C.; Revest, M.; Dubee, V.; Tattevin, P.; Group, R.C.S. Utility of hyposmia and hypogeusia for the diagnosis of COVID-19. Lancet Infect. Dis. 2020, 20, 1014-1015. [CrossRef]

220. Politi, L.S.; Salsano, E.; Grimaldi, M. Magnetic Resonance Imaging Alteration of the Brain in a Patient with Coronavirus Disease 2019 (COVID-19) and Anosmia. JAMA Neurol. 2020, 77, 1028-1029. [CrossRef]

221. Laurendon, T.; Radulesco, T.; Mugnier, J.; Gerault, M.; Chagnaud, C.; El Ahmadi, A.A.; Varoquaux, A. Bilateral transient olfactory bulb edema during COVID-19-related anosmia. Neurology 2020, 95, 224-225. [CrossRef]

222. Keyhan, S.O.; Fallahi, H.R.; Cheshmi, B. Dysosmia and dysgeusia due to the 2019 Novel Coronavirus; a hypothesis that needs further investigation. Maxillofac. Plast. Reconstr. Surg. 2020, 42, 9. [CrossRef] [PubMed]

223. Fodoulian, L.; Tuberosa, J.; Rossier, D.; Boillat, M.; Kan, C.; Pauli, V.; Egervari, K.; Lobrinus, J.A.; Landis, B.N.; Carleton, A.; et al. SARS-CoV-2 Receptors and Entry Genes Are Expressed in the Human Olfactory Neuroepithelium and Brain. iScience 2020, 23, 101839. [CrossRef] [PubMed]

224. Moein, S.T.; Hashemian, S.M.; Mansourafshar, B.; Khorram-Tousi, A.; Tabarsi, P.; Doty, R.L. Smell dysfunction: A biomarker for COVID-19. Int. Forum Allergy Rhinol. 2020, 10, 944-950. [CrossRef] [PubMed]

225. Wijeratne, T.; Crewther, S. Post-COVID 19 Neurological Syndrome (PCNS); a novel syndrome with challenges for the global neurology community. J. Neurol. Sci. 2020, 419, 117179. [CrossRef] [PubMed]

226. Wijeratne, T.; Crewther, S. COVID-19 and long-term neurological problems: Challenges ahead with Post-COVID-19 Neurological Syndrome. Aust. J. Gen. Pract. 2021, 50. [CrossRef] [PubMed]

227. Zou, X.; Chen, K.; Zou, J.; Han, P.; Hao, J.; Han, Z. Single-cell RNA-seq data analysis on the receptor ACE2 expression reveals the potential risk of different human organs vulnerable to 2019-nCoV infection. Front. Med. 2020, 14, 185-192. [CrossRef]

228. Gironacci, M.M.; Cerniello, F.M.; Longo Carbajosa, N.A.; Goldstein, J.; Cerrato, B.D. Protective axis of the renin-angiotensin system in the brain. Clin. Sci. 2014, 127, 295-306. [CrossRef] [PubMed]

229. Xu, P.; Sriramula, S.; Lazartigues, E. ACE2/ANG-(1-7)/Mas pathway in the brain: The axis of good. Am. J. Physiol. Regul. Integr. Comp. Physiol. 2011, 300, R804-R817. [CrossRef]

230. Xu, Z.; Shi, L.; Wang, Y.; Zhang, J.; Huang, L.; Zhang, C.; Liu, S.; Zhao, P.; Liu, H.; Zhu, L.; et al. Pathological findings of COVID-19 associated with acute respiratory distress syndrome. Lancet Respir. Med. 2020, 8, 420-422. [CrossRef]

231. Tan, M.; Liu, Y.; Zhou, R.; Deng, X.; Li, F.; Liang, K.; Shi, Y. Immunopathological characteristics of coronavirus disease 2019 cases in Guangzhou, China. Immunology 2020, 160, 261-268. [CrossRef] [PubMed]

232. Li, X.; Geng, M.; Peng, Y.; Meng, L.; Lu, S. Molecular immune pathogenesis and diagnosis of COVID-19. J. Pharm. Anal. 2020, 10, 102-108. [CrossRef] [PubMed]

233. Zhang, C.; Wu, Z.; Li, J.W.; Zhao, H.; Wang, G.Q. Cytokine release syndrome in severe COVID-19: Interleukin-6 receptor antagonist tocilizumab may be the key to reduce mortality. Int. J. Antimicrob. Agents 2020, 55, 105954. [CrossRef] [PubMed]

234. Hess, D.C.; Eldahshan, W.; Rutkowski, E. COVID-19-Related Stroke. Transl. Stroke Res. 2020, 11, 322-325. [CrossRef] [PubMed]

235. Tang, N.; Bai, H.; Chen, X.; Gong, J.; Li, D.; Sun, Z. Anticoagulant treatment is associated with decreased mortality in severe coronavirus disease 2019 patients with coagulopathy. J. Thromb. Haemost. 2020, 18, 1094-1099. [CrossRef] [PubMed]

236. Wijeratne, T.; Wijeratne, C. Clinical utility of serial systemic immune inflammation indices (SSIIi) in the context of post covid-19 neurological syndrome (PCNS). J. Neurol. Sci. 2021, 423, 117356. [CrossRef]

237. Remy, K.E.; Mazer, M.; Striker, D.A.; Ellebedy, A.H.; Walton, A.H.; Unsinger, J.; Blood, T.M.; Mudd, P.A.; Yi, D.J.; Mannion, D.A.; et al. Severe immunosuppression and not a cytokine storm characterizes COVID-19 infections. JCI Insight 2020, 5. [CrossRef]

238. Coperchini, F.; Chiovato, L.; Croce, L.; Magri, F.; Rotondi, M. The cytokine storm in COVID-19: An overview of the involvement of the chemokine/chemokine-receptor system. Cytokine Growth Factor Rev. 2020, 53, 25-32. [CrossRef]

239. Zhang, B.; Zhou, X.; Zhu, C.; Song, Y.; Feng, F.; Qiu, Y.; Feng, J.; Jia, Q.; Song, Q.; Zhu, B.; et al. Immune Phenotyping Based on the Neutrophil-to-Lymphocyte Ratio and IgG Level Predicts Disease Severity and Outcome for Patients with COVID-19. Front. Mol. Biosci. 2020, 7, 157. [CrossRef]

240. Fu, Y.; Cheng, Y.; Wu, Y. Understanding SARS-CoV-2-Mediated Inflammatory Responses: From Mechanisms to Potential Therapeutic Tools. Virol. Sin. 2020, 35, 266-271. [CrossRef]

241. Takada, A.; Kawaoka, Y. Antibody-dependent enhancement of viral infection: Molecular mechanisms and in vivo implications. Rev. Med. Virol. 2003, 13, 387-398. [CrossRef] 